\title{
New heterobimetallic ferrocenyl derivatives: Evaluation of their potential as prospective agents against trypanosomatid parasites and Mycobacterium tuberculosis
}

\author{
Feriannys Rivas $^{\mathrm{a}}$, Andrea Medeiros ${ }^{\mathrm{b}, \mathrm{c}}$, Esteban Rodríguez Arce ${ }^{\mathrm{a}}$, Marcelo Comini ${ }^{\mathrm{b}}$, \\ Camila M. Ribeiro ${ }^{\mathrm{d}}$, Fernando R. Pavan ${ }^{\mathrm{d}}$, Dinorah Gambino ${ }^{\mathrm{a}, *}$ \\ a Área Química Inorgánica, Facultad de Química, Universidad de la República, Montevideo, Uruguay \\ b Group Redox Biology of Trypanosomes, Institut Pasteur Montevideo, Montevideo, Uruguay \\ c Departamento de Bioquímica, Facultad de Medicina, Universidad de la República, Montevideo, Uruguay \\ ${ }^{\mathrm{d}}$ Faculdade de Ciências Farmacêuticas, UNESP, Araraquara, Brazil
}

A R T I C L E IN F O

\section{Keywords:}

Ferrocenyl compounds

Tropolone derivatives

Trypanosoma brucei

Mycobacterium tuberculosis

Leishmaniasis

\begin{abstract}
A B S T R A C T
Searching for prospective agents against infectious diseases, four new ferrocenyl derivatives, [M(L)(dppf)4] $\left(\mathrm{PF}_{6}\right)$, with $\mathrm{M}=\mathrm{Pd}(\mathrm{II})$ or $\mathrm{Pt}(\mathrm{II})$, dppf = 1,1'-bis(dipheny1phosphino) ferrocene and $\mathrm{HL}=$ tropolone (HTrop) or hinokitiol (HHino), were synthesized and characterized. Complexes and ligands were evaluated against the bloodstream form of T. brucei, L. infantum amastigotes, M. tuberculosis (MTB) sensitive strain and MTB clinical isolates. Complexes showed a significant increase of the anti-T. brucei activity with respect to the free ligands ( $>$ 28- and > 46-fold for Trop and 6- and 22-fold for Hino coordinated to Pt-dppf and Pd-dppf, respectively), yielding IC $_{50}$ values $<5 \mu \mathrm{M}$. The complexes proved to be more potent than the antitrypanosomal drug Nifurtimox. The new ferrocenyl derivatives were more selective towards the parasite than the free ligands. The Pt compounds were less toxic on J774 murine macrophages (mammalian cell model), than the Pd ones, showing selectivity index values ( $\mathrm{SI}=\mathrm{IC}_{50}$ murine macrophage/IC $\mathrm{I}_{50} \mathrm{~T}$. brucei) up to 23 . Generation of the $\{\mathrm{M}$-dppf $\}$ compounds lead to a slightly positive impact on the anti-leishmanial potency. Although the ferrocenyl derivatives were more active on sensitive MTB than the free ligands ( $\mathrm{MIC}_{90}=9.88-14.73 \mu \mathrm{M}$ ), they showed low selectivity towards the pathogen. Related to the mechanism of action, the antiparasitic effect cannot be ascribed to an interference of the compounds with the thiol-redox homeostasis of the pathogen. Fluorescence measurements pointed at DNA as a probable target of the new compounds. $[\mathrm{Pt}(\mathrm{Trop})(\mathrm{dppf})]\left(\mathrm{PF}_{6}\right)$ and $[\mathrm{Pt}(\mathrm{Hino})(\mathrm{dppf})]$ $\left(\mathrm{PF}_{6}\right)$ could be considered prospective anti-T. brucei agents that deserve further research.
\end{abstract}

\section{Introduction}

Infectious diseases represent a tremendous health burden worldwide. Among them, a group of twenty communicable and poverty-related diseases, that affect about one billion people living in 149 countries, have received low attention from the pharmaceutical industry mainly due to little prospect of generating financial profit. Among these neglected diseases, three parasitic illnesses caused by genetically related trypanosomatid protozoa are major health concerns in the developing world: American Trypanosomiasis (Chagas' disease), Human African Trypanosomiasis (HAT, sleeping sickness) and Leishmaniasis. The genome of the three main parasites responsible of these diseases (Trypanosoma cruzi, Trypanosoma brucei and Leishmania major) shows a high percentage of inter-species conservation of genes encoding for indispensable and, sometimes, unique proteins. This offers the opportunity to develop wide spectrum drugs that could affect several related parasites. Additionally, these diseases are often co-endemic in certain regions of the world, Leishmaniasis and Chagas' disease in South America and Leishmaniasis and HAT in Africa. This fact has led to the interest in developing drugs suitable for the treatment of multiple and biologically related pathogens [1-4]. HAT and Leishmaniasis are both parasitic diseases of interest in this work. HAT, caused by two strains of Trypanosoma brucei (T. brucei) (Trypanosoma brucei gambiense and Trypanosoma brucei rhodesiense), is currently a resurgent disease with epidemic character in many regions of sub-Saharan Africa that can be fatal if not treated. The lack of surveillance, health care and new treatments and the emergence of resistance to old drugs favored the reappearance of the disease. The drugs currently available for the treatment show

\footnotetext{
* Corresponding author.

E-mail address: dgambino@fq.edu.uy (D. Gambino).
} 
toxicity problems and variable efficacy depending on the type and stage of the disease [5-8]. Leishmaniases are a group of diseases caused by more than twenty Leishmania species. The parasites are transmitted to humans by the bite of an infected female phlebotomine sandfly insect vector. There are three main forms of the disease: cutaneous, visceral or kala-azar, and mucocutaneous. Leishmaniasis currently threatens 350 million people in 88 countries around the world being prevalent in four continents. Leishmania-HIV co-infection has been reported in 34 countries in Africa, Asia, Europe and South America and it intensifies the burden of visceral and cutaneous leishmaniasis by causing severe forms that are more difficult to manage [9-11]. Overall, available drugs for the treatment of both diseases are decades old and/or suffer from limited efficacy, undesirable collateral effects and development of resistance.

On the other hand, Tuberculosis (TB) is a highly contagious infectious disease caused by Mycobacterium tuberculosis (MTB). Although curable and preventable, it remains on the leading causes of death in the world being the most deadly infectious disease worldwide. Over $95 \%$ of the deaths occur in low- and middle-income countries. According to the World Health Organization 10.4 million people developed TB in 2016. In addition, it is estimated that 2 to 3 billion people have MTB latently in the lungs and about 5 to $15 \%$ of these people will develop the disease at some point [12,13]. The risk of infection is higher in persons with impaired immune system. Therefore, TB is a leading killer of HIV-positive people. Only few drugs are active against M. tuberculosis bacilli. Moreover, there is an increasing emergence of multi-drug resistant (MDR, resistant to isoniazid and rifampicin) and extensively drug resistant (XDR, resistant to isoniazid and rifampicin and, also to fluoroquinolones and second-line drugs) MTB strains. For instance, about half million people developed MDR-TB in the world in 2016 and, additionally, 110,000 people with rifampicin-resistant TB also required second line treatment in the same year. The continuing spread of drug-resistant TB is one of the most urgent and difficult challenges facing the control of the disease. This leads to an urgent need of developing new drugs acting through unprecedented mechanisms [14-18].

Our group is currently focused on the rational design of prospective metal-based drugs for the treatment of diseases caused by trypanosomatids and tuberculosis based on bioactive ligands, pharmacologically active metals and selected organometallic cores. This strategy, based on the paradigm of the metal-ligand synergism, could provide drugs capable of modulating multiple targets simultaneously and bearing improved biological properties [19-21]. According to this interest, we have developed organometallic compounds bearing antitrypanosomal activity including $\left\{\mathrm{Ru}^{\mathrm{II}}-p\right.$-cymene $\},\left\{\mathrm{Ru}^{\mathrm{II}}\right.$-cyclopentadienyl $\},\{$ fac$\left.\operatorname{Re}^{\mathrm{I}}(\mathrm{CO})_{3}\right\}$ and $\left\{\mathrm{M}^{\mathrm{II}}\right.$-dppf $\}$ cores, where $\mathrm{M}=\mathrm{Pd}$ or Pt and dppf $=1,1^{\prime}$-bis (diphenylphosphino) ferrocene [22-30].

In particular, the "sandwich type" ferrocene moiety has shown high potential in the development of novel organometallic drugs. For instance, compounds including it, like the antitumoral ferrocifen and the antimalarial ferroquine, have entered the phase of clinical trials. Ferrocene derivatives are usually stable in air and in solution. In addition, they usually show low cytotoxicity and adequate lipophilicity that favor compound's penetration across cell membranes [31-33].

In this context, we identified a $\left\{\mathrm{Pt}^{\mathrm{II}}-\mathrm{dppf}\right\}$ compound including the bioactive ligand pyridine-2-thiolate-1-oxide (Hmpo), [ $\left.\mathrm{Pt}^{\mathrm{II}}(\mathrm{mpo})(\mathrm{dppf})\right]$ $\left(\mathrm{PF}_{6}\right)$, as a hit compound and performed metallomics and proteomics on T. cruzi for the first time for a metal-based prospective drug [29,34]. The promising results obtained for this Pt complex encouraged us to further study the physicochemical and biological behavior of other series of related complexes obtained by modifying the hit compound. The new families of compounds retained the M-dppf co-ligand and different families of bioactive bidentate ligands were included instead of mpo. Among these bioactive ligands two tropolone derivatives were selected in the current work: Tropolone (HTrop) and Hinokitiol (HHino) (Fig. 1).
Tropolones are considered lead-like natural products in Medicinal Chemistry. The tropolone scaffold is characterized by a relatively low molecular weight, ample sites for chemical modifications and metalbinding functionality. Tropolone, hinokitiol and their derivatives, including metal compounds, have shown antitumoral and antimicrobial activities, among others [35,36].

In this work, 1,1'-bis(dipheny1phosphino) ferrocene hexafluorophosphate compounds $\left[\mathrm{M}^{\mathrm{II}}(\mathrm{Trop})(\mathrm{dppf})\right]\left(\mathrm{PF}_{6}\right)$ and $\left[\mathrm{M}^{\mathrm{II}}(\mathrm{Hino})\right.$ (dppf)] $\left(\mathrm{PF}_{6}\right)$, where $\mathrm{M}=\mathrm{Pd}$ or $\mathrm{Pt}$, were synthesized and fully characterized in the solid state and in solution. The biological activity of the four compounds was evaluated against T. brucei, L. infantum and $M$. tuberculosis (MTB) as well as on murine macrophages and human lung cells, both considered suitable mammalian cell models for determining selectivity towards trypanosomatids and MTB, respectively. Effects on redox metabolism of $T$. brucei and interaction with DNA were explored to get insight into the potential mechanism of action on the parasite.

\section{Materials and methods}

\subsection{Materials}

All common laboratory chemicals were purchased from commercial sources and used without further purification. Tropolone and Hinokitiol were purchased from Sigma Aldrich. Hinokitiol and tropolone sodium salts (NaHino $\cdot 2 \mathrm{H}_{2} \mathrm{O}$ and NaTrop) were prepared according to a literature procedure [37]. $\left[\mathrm{MCl}_{2}(\mathrm{dppf})\right] \cdot \mathrm{CHCl}_{3}$ precursors were synthesized according to a previously reported procedure by heating for $30 \mathrm{~min}$ an equimolar mixture of $\left[\mathrm{MCl}_{2}(\mathrm{dmso})_{2}\right]$ and dppf in $\mathrm{CHCl}_{3}$ [38].

\subsection{Synthesis of $\left[M^{I I}(T r o p)(d p p f)\right]\left(P F_{6}\right)$ and $\left[M^{I I}(\right.$ Hino $\left.)(d p p f)\right]\left(P F_{6}\right)$ compounds}

The $[\mathrm{M}(\mathrm{Trop})(\mathrm{dppf})]\left(\mathrm{PF}_{6}\right)$ and $[\mathrm{M}(\mathrm{Hino})(\mathrm{dppf})]\left(\mathrm{PF}_{6}\right)$ compounds were synthesized by the following procedure: $50 \mathrm{mg}$ of the precursor $\left[\mathrm{MCl}_{2}(\mathrm{dppf})\right] \quad\left(0.059 \mathrm{mmol} \quad\left[\mathrm{PdCl}_{2}(\mathrm{dppf})\right] \cdot \mathrm{CHCl}_{3}\right.$ or $0.053 \mathrm{mmol}$ $\left[\mathrm{PtCl}_{2}\right.$ (dppf)]. $\mathrm{CHCl}_{3}$ ) were dissolved in $10 \mathrm{~mL}$ methanol. To this solution, an equimolar amount of $\mathrm{NaHino} \cdot 2 \mathrm{H}_{2} \mathrm{O}(13.1 \mathrm{mg}$ for the Pd compound and $11.8 \mathrm{mg}$ for the Pt compound) or NaTrop (8.5 $\mathrm{mg}$ for the Pd compound and $7.7 \mathrm{mg}$ for the Pt compound) dissolved in $5 \mathrm{~mL}$ methanol was added. The mixture was shaken at room temperature for $24 \mathrm{~h}$ for the Trop compounds and $6 \mathrm{~h}$ at reflux for the Hino compounds. The solution was evaporated up to $5 \mathrm{~mL}$ and centrifugated. $\mathrm{NaPF}_{6}$ dissolved in a minimal volume of methanol $(14.8 \mathrm{mg}, 0.88 \mathrm{mmol}$, for the Pd compounds and $13.4 \mathrm{mg}, 0.079 \mathrm{mmol}$, for the Pt compounds) was added. The solution was kept in refrigerator during $24 \mathrm{~h}$. Pd compounds were isolated by centrifugation as brown reddish solids and the $\mathrm{Pt}$ analogues as orange-yellow ones. Solids were washed with small portions of methanol. The four compounds were recrystallized from a dichloromethane solution of the compounds by diffusion with hexane. Single crystals suitable for $\mathrm{X}$ ray diffraction studies were obtained in the four cases.

[Pd(Trop)(dppf)] ( $\left.\mathbf{P F}_{6}\right)$, Pd-dppf-Trop. Yield: $27 \mathrm{mg}, 49 \%$. Anal. calc. for $\mathrm{C}_{41} \mathrm{H}_{33} \mathrm{~F}_{6} \mathrm{FeO}_{2} \mathrm{P}_{3} \mathrm{Pd}$ : C, 53.13; H, 3.59. Found: C, 52.93; H, 3.57 .

[Pt(Trop)(dppf)] $\left(\mathrm{PF}_{6}\right)$, Pt-dppf-Trop. Yield: $22 \mathrm{mg}, 41 \%$. Anal. calc. for $\mathrm{C}_{41} \mathrm{H}_{33} \mathrm{~F}_{6} \mathrm{FeO}_{2} \mathrm{P}_{3} \mathrm{Pt}$ : C, 48.49; H, 3.28. Found: C, 48.51; H, 3.19.

[Pd(Hino)(dppf)] $\left(\mathbf{P F}_{6}\right)$, Pd-dppf-Hino. Yield: $25 \mathrm{mg}, 44 \%$. Anal. calc. for $\mathrm{C}_{44} \mathrm{H}_{39} \mathrm{~F}_{6} \mathrm{FeO}_{2} \mathrm{P}_{3} \mathrm{Pd}$ : C, 54.56; H, 4.03. Found: C, 54.26; H, 3.98.

[Pt(Hino)(dppf)] (PF $\left.{ }_{6}\right)$, Pt-dppf-Hino. Yield: $20 \mathrm{mg}, 35 \%$. Anal. calc. for $\mathrm{C}_{44} \mathrm{H}_{39} \mathrm{~F}_{6} \mathrm{FeO}_{2} \mathrm{P}_{3} \mathrm{Pt}$ : C, 49.98; H, 3.69. Found: C, 49.86; H, 3.74.

\subsection{Physicochemical characterization}

$\mathrm{C}$ and $\mathrm{H}$ analyses were carried out with a Thermo Scientific Flash 2000 elemental analyzer. Conductimetric measurements were done 


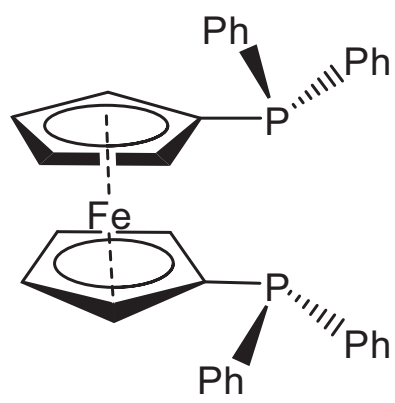

dppf

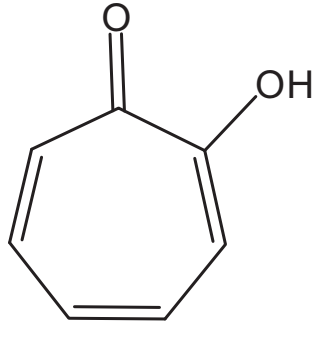

HTrop
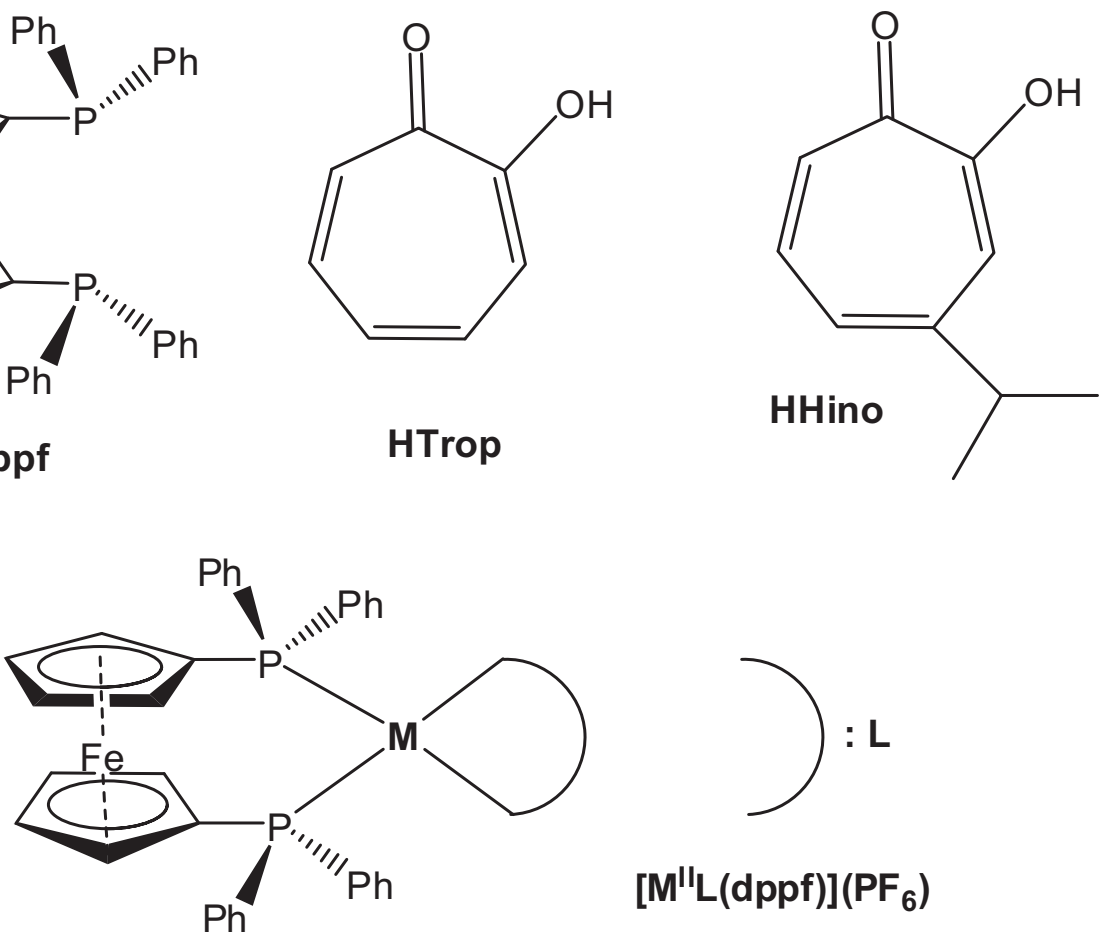

$\left[M^{\prime \prime} L(d p p f)\right]\left(P F_{6}\right)$

Fig. 1. Structures of 1,1'-bis(dipheny1phosphino) ferrocene (dppf), tropolone (HTrop), hinokitiol (HHino) and of the new heterobimetallic core in [M $\left.{ }^{\mathrm{II}}(\mathrm{Trop})(\mathrm{dppf})\right]$ $\left(\mathrm{PF}_{6}\right)$ and $\left[\mathrm{M}^{\mathrm{II}}(\mathrm{Hino})(\mathrm{dppf})\right]\left(\mathrm{PF}_{6}\right)$ complexes.

over time ( 7 days) at $25^{\circ} \mathrm{C}$ in $10^{-3} \mathrm{M}$ DMSO solutions using a Conductivity Meter 4310 Jenway to determine the type of electrolyte and to assess the stability of the complexes in such medium [39]. The FTIR spectra $\left(4000-400 \mathrm{~cm}^{-1}\right)$ were measured as $\mathrm{KBr}$ pellets with a Shimadzu IRPrestige-21 instrument. ${ }^{1} \mathrm{H}$ NMR spectra were recorded in DMSO- $d_{6}$ at $30^{\circ} \mathrm{C}$ on a Bruker DPX-400 instrument at $400 \mathrm{MHz}$. Homonuclear correlation (COSY) experiments were carried out with the same instrument. Tetramethylsilane was used as the internal standard. Chemical shifts are reported in ppm.

\subsection{X-ray diffraction study of $[M(L)(d p p f)]\left(P F_{6}\right)$ compounds, where $M=P d(I I)$ or Pt(II) and $L=$ Trop or Hino}

Single crystals suitable for X-ray diffraction studies of the four compounds, $\quad\left[\mathrm{Pd}^{\mathrm{II}}\right.$ (Trop) $\left.(\mathrm{dppf})\right]\left(\mathrm{PF}_{6}\right), \quad\left[\mathrm{Pt}^{\mathrm{II}}(\mathrm{Trop})(\mathrm{dppf})\right]\left(\mathrm{PF}_{6}\right)$, $\left[\mathrm{Pd}^{\mathrm{II}}(\mathrm{Hino})(\mathrm{dppf})\right]\left(\mathrm{PF}_{6}\right)$ and $\left[\mathrm{Pt}^{\mathrm{II}}(\mathrm{Hino})(\mathrm{dppf})\right]\left(\mathrm{PF}_{6}\right)$, were obtained by slow diffusion of hexane into dichloromethane solutions of the complexes. Measurements were performed on a Bruker D8 Venture diffractometer with multilayer mirror monochromated CuKa

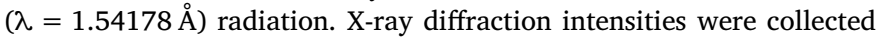
and integrated with APEX2 v2014.5-0 (Bruker AXS). These intensities were scaled and the data were corrected empirically for absorption (employing the multi-scan method) with the SADABS V2014/2 (Bruker AXS Inc.) program. The structure was solved by direct methods with the SHELXT-2014 [40] and the molecular model developed by alternated cycles of Fourier methods and full-matrix least-squares refinement with Olex2 [41]. The crystal structure of $\left[\mathrm{Pd}^{\mathrm{II}}(\mathrm{Hino})(\mathrm{dppf})\right]\left(\mathrm{PF}_{6}\right)$ and $\left[\mathrm{Pt}^{\mathrm{II}}(\mathrm{Hino})(\mathrm{dppf})\right]\left(\mathrm{PF}_{6}\right)$ contains solvent accessible voids (Pd: $1261.9 \AA^{3}$ /unit cell, Pt: $1265.3 \AA^{3} /$ unit cell) filled with disordered solvent molecules. Their contribution to the structure factors was secured by back-Fourier transformation using the SQUEEZE routine of OLEX 2 resulting in 265.2 electrons/unit cell in palladium complex and 305.6 electrons/unit cell in platinum complex [42]. The hydrogen atoms were positioned on stereo-chemical basis and refined with the riding model. Crystal data, data collection procedure, structure determination methods and refinement results are summarized in Table 1.

\subsection{Biological studies}

\subsubsection{Viability assays for bloodstream Trypanosoma brucei brucei}

The anti-trypanosomal activity of the compounds and their potential interference with the intracellular thiol-redox homeostasis was evaluated against bloodstream T. b. brucei (monomorphic strain 427, cell line 449-hGrxroGFP2) [43]. The parasites were cultivated aerobically in HMI-9 medium supplemented with $10 \%(\mathrm{v} / \mathrm{v})$ fetal bovine serum (FBS), $10 \mathrm{U} / \mathrm{mL}$ penicillin, $10 \mu \mathrm{g} / \mathrm{mL}$ streptomycin, $0.2 \mu \mathrm{g} / \mathrm{mL}$ phleomycin and $5 \mathrm{mg} / \mathrm{mL}$ hygromycin, inside a humidified incubator at $37^{\circ} \mathrm{C}$ and $5 \% \mathrm{CO}_{2}$. Stock solutions ( 3 to $20 \mathrm{mM}$ ) in DMSO were prepared for each compound according to their solubility. All assays were started with parasites from an exponential-phase culture. Assays to estimate cytotoxicity were conducted, as previously described, using propidium iodide (PI, final concentration $2 \mu \mathrm{g} / \mathrm{mL}$ ) as exclusion dye and BD Accuri C6 (BD Biosciences) or $\mathrm{CyAn}^{\mathrm{TM}} \mathrm{ADP}$ (DakoCytomation) flow cytometers [44]. All compounds were tested at different concentrations to estimate their $\mathrm{IC}_{50}$ values. The concentration of DMSO in all conditions tested was $\leq 1 \%(\mathrm{v} / \mathrm{v})$. The reference drug Nifurtimox was assayed at its $\mathrm{IC}_{50}$ value of $15 \mu \mathrm{M}$. The control consisted of parasites grown in medium with DMSO 1\% (v/v). All conditions were tested by triplicate. $\mathrm{IC}_{50}$ values were obtained from dose-response curves, fitted to a sigmoidal Boltzmann equation (errors calculated using errors' propagation) or extrapolated from non-linear fitting plots. The errors are expressed as one standard deviation (S.D., estimated as $\sigma^{n-1}$ ).

\subsubsection{Cytotoxicity assay on murine macrophages}

Mouse macrophages from the cell line J774 (ATCC ${ }^{\circledR}$ TIB- $67^{\mathrm{TM}}$ ) were cultivated in a humidified $5 \% \mathrm{CO}_{2} / 95 \%$ air atmosphere at $37^{\circ} \mathrm{C}$ in DMEM medium supplemented with $10 \%(\mathrm{v} / \mathrm{v})$ FBS, $10 \mathrm{U} / \mathrm{mL}$ penicillin and $10 \mu \mathrm{g} / \mathrm{mL}$ streptomycin. The experimental protocol for the determination of $\mathrm{IC}_{50}$ values was previously described [23], except that $200 \mu \mathrm{L}$ of a cell suspension at $6 \times 10^{4}$ cells $/ \mathrm{mL}$ was added per well in a 96-well culture plate. The cytotoxicity of the compounds was evaluated at five different concentrations $(0.01-100 \mu \mathrm{M})$ in triplicates and using the WST-1 reagent (Roche). A control included cells treated with DMSO 
Table 1

Crystal data and structure refinement results for $[\mathrm{M}(\mathrm{Trop})(\mathrm{dpp})]\left(\mathrm{PF}_{6}\right)$ and $[\mathrm{M}(\mathrm{Hino})(\mathrm{dppf})]\left(\mathrm{PF}_{6}\right)$ complexes.

\begin{tabular}{|c|c|c|c|c|}
\hline & Pd-dppf-Trop & Pt-dppf-Trop & Pd-dppf-Hino & Pt-dppf-Hino \\
\hline Empirical formula & $\mathrm{C}_{41} \mathrm{H}_{33} \mathrm{~F}_{6} \mathrm{FeO}_{2} \mathrm{P}_{3} \mathrm{Pd}[+$ solvent $]$ & $\mathrm{C}_{41} \mathrm{H}_{33} \mathrm{~F}_{6} \mathrm{FeO}_{2} \mathrm{P}_{3} \mathrm{Pt}$ [+ solvent $]$ & $\mathrm{C}_{44} \mathrm{H}_{39} \mathrm{~F}_{6} \mathrm{FeO}_{2} \mathrm{P}_{3} \mathrm{Pd}$ & $\mathrm{C}_{44} \mathrm{H}_{39} \mathrm{~F}_{6} \mathrm{FeO}_{2} \mathrm{P}_{3} \mathrm{Pt}$ \\
\hline Formula weight & 926.83 & 1015.52 & 968.91 & 1057.60 \\
\hline Temperature (K) & $273(2)$ & $273(2)$ & $298(2)$ & $273(2)$ \\
\hline Wavelength (̊̊) & $\mathrm{CuK} \alpha(\lambda=1.54178)$ & & & \\
\hline Crystal system & Monoclinic & & & \\
\hline Space group & $P 2_{1} / c$ & & & \\
\hline \multicolumn{5}{|l|}{ Unit cell dimensions } \\
\hline a $(\AA)$ & $10.7256(3)$ & $10.7542(4)$ & $10.0534(6)$ & $10.0987(2)$ \\
\hline b $(\AA)$ & $27.1890(9)$ & $27.1988(9)$ & $30.9093(17)$ & $30.9325(6)$ \\
\hline c $(\AA)$ & $16.0724(5)$ & $16.0624(5)$ & $13.7850(8)$ & $13.7258(3)$ \\
\hline$\beta\left(^{\circ}\right)$ & $99.262(2)$ & $99.979(2)$ & $105.679(3)$ & $105.56(1)$ \\
\hline Volume $\left(\AA^{3}\right)$ & $4625.9(2)$ & $4634.1(3)$ & $4124.2(4)$ & $4130.6(2)$ \\
\hline $\begin{array}{l}\text { Z, density (calculated, } \\
\qquad \mathrm{g} \mathrm{cm}^{-1} \text { ) }\end{array}$ & $4,1.331$ & $4,1.456$ & $4,1.560$ & $4,1.701$ \\
\hline $\begin{array}{l}\text { Absorption coefficient } \\
\qquad\left(\mathrm{mm}^{-1}\right)\end{array}$ & 7.103 & 9.524 & 7.993 & 10.712 \\
\hline $\mathrm{F}(000)$ & 1864.0 & 1992.0 & 1960.0 & 2088.0 \\
\hline Crystal shape/color & Rectangular prism/yellow & Prism/yellow & Rectangular prism/brown & Rectangular prism/yellow \\
\hline Crystal size $\left(\mathrm{mm}^{3}\right)$ & $0.279 \times 0.103 \times 0.064$ & $0.332 \times 0.119 \times 0.084$ & $0.550 \times 0.150 \times 0.110$ & $0.072 \times 0.141 \times 0.225$ \\
\hline $\begin{array}{l}\vartheta \text {-Range }\left({ }^{\circ}\right) \text { for data } \\
\quad \text { collection }\end{array}$ & 2.79 to 68.45 & 2.79 to 70.24 & 2.86 to 79.34 & 2.86 to $72.55^{\circ}$ \\
\hline Index ranges & $\begin{array}{l}-11 \leq \mathrm{h} \leq 12,-32 \leq \mathrm{k} \leq 32 \\
-19 \leq 1 \leq 19\end{array}$ & $\begin{array}{l}-11 \leq \mathrm{h} \leq 13,-33 \leq \mathrm{k} \leq 33 \\
-19 \leq 1 \leq 19\end{array}$ & $\begin{array}{l}-12 \leq \mathrm{h} \leq 11,0 \leq \mathrm{k} \leq 38 \\
0 \leq 1 \leq 17\end{array}$ & $\begin{array}{l}-12 \leq \mathrm{h} \leq 11,-38 \leq \mathrm{k} \leq 38 \\
-16 \leq \mathrm{l} \leq 16\end{array}$ \\
\hline Reflections collected & 70,615 & 83,965 & 8635 & 74,511 \\
\hline Independent reflections & 8432 & 8780 & 8635 & 8163 \\
\hline $\begin{array}{l}\text { Observed reflections } \\
\qquad[I>2 \sigma(\mathrm{I})]\end{array}$ & 7281 & 7513 & 7002 & 7679 \\
\hline Completeness (\%) & 99.4 & 99.4 & 96.4 & 99.6 \\
\hline Absorption correction & Multi-scan & Multi-scan & Multi-scan & Multi-scan \\
\hline $\begin{array}{l}\text { Max. and min. } \\
\text { transmission }\end{array}$ & 0.7531 and 0.4430 & 0.7533 and 0.3554 & 0.4730 and 0.2880 & 0.5130 and 0.1970 \\
\hline Refinement method & Full-matrix least-squares on F2 & & & \\
\hline $\begin{array}{l}\text { Data/restraints/ } \\
\text { parameters }\end{array}$ & $8432 / 42 / 487$ & $8780 / 42 / 487$ & $8635 / 39 / 538$ & $8163 / 0 / 524$ \\
\hline Goodness-of-fit on F2 & 1.077 & 1.039 & 1.087 & 0.986 \\
\hline $\begin{array}{l}{\text { Final } R \text { indices }^{\mathrm{a}}} \\
\qquad[\mathrm{I}>2 \sigma(\mathrm{I})]\end{array}$ & $\mathrm{R}_{1}=0.0606, \mathrm{wR}_{2}=0.1402$ & $\mathrm{R}_{1}=0.0313, \mathrm{w} R_{2}=0.0725$ & $\mathrm{R}_{1}=0.0459, \mathrm{w} R_{2}=0.0990$ & $\mathrm{R}_{1}=0.0271, \mathrm{wR}_{2}=0.1071$ \\
\hline $\mathrm{R}$ indices (all data) & $\mathrm{R}_{1}=0.0691, \mathrm{wR}_{2}=0.1446$ & $\mathrm{R}_{1}=0.0383, \mathrm{wR}_{2}=0.0752$ & $\mathrm{R}_{1}=0.0651, \mathrm{wR}_{2}=0.1104$ & $\mathrm{R}_{1}=0.0293, \mathrm{wR}_{2}=0.1103$ \\
\hline $\begin{array}{l}\text { Largest diff. peak and } \\
\text { hole (e. } \AA \text { - }-3)\end{array}$ & 1.11 and -0.67 & 0.97 and -0.67 & 0.46 and -0.50 & 0.721 and -1.333 \\
\hline
\end{tabular}

${ }^{\mathrm{a}} R_{1}=\Sigma|| F_{o}|-| F_{c}|| / \Sigma\left|F_{o}\right|, w R_{2}=\left[\Sigma w\left(\left|F_{o}\right|^{2}-\left|F_{c}\right|^{2}\right)^{2} / \Sigma w\left(\left|F_{o}\right|^{2}\right)^{2}\right]^{1 / 2}$.

$1 \%(\mathrm{v} / \mathrm{v})$. Absorbance at $450 \mathrm{~nm}$, corresponding to the formazan dye produced by metabolically active cells, was measured with an EL 800 microplate reader. $\mathrm{IC}_{50}$ values were obtained from drug-response curves as described above for the T. brucei assay and the associated errors are expressed as S.D.

\subsubsection{Biological activity against amastigotes of Leishmania infantum}

L. infantum promastigotes (MHOM MA67I7MAP263, cell line kindly provided by Dr. H. Castro and Dr. A. Thomas, IBMC, Universidade do Porto, Portugal) were cultured at $28^{\circ} \mathrm{C}$ in RPMI 1640 Glutamax supplemented with $10 \%(\mathrm{v} / \mathrm{v}) \mathrm{FBS}, 10 \mathrm{U} / \mathrm{mL}$ penicillin, $10 \mu \mathrm{g} / \mathrm{mL}$ streptomycin and $25 \mathrm{mM}$ HEPES-Na pH 7.4. Macrophage (cell line J774) infection was performed with parasites grown up to the stationary phase. Briefly, macrophages were seeded $(0.5 \mathrm{~mL} /$ well of a suspension with $1 \times 10^{5}$ cells $/ \mathrm{mL}$ ) in a 24-well plate containing a glass coverslip in the bottom and grown for $24 \mathrm{~h}$ as described above. Two million parasites were added onto the macrophages (ratio of 40:1) and the plates were re-incubated for $24 \mathrm{~h}\left(2 \mathrm{~h}\right.$ at room temperature and $22 \mathrm{~h}$ at $\left.37^{\circ} \mathrm{C}\right)$. After removing the medium, the wells were washed 3 times with PBS and compounds diluted in DMEM medium supplemented with $1 \%(\mathrm{v} / \mathrm{v})$ FBS, $10 \mathrm{U} / \mathrm{mL}$ penicillin and $10 \mu \mathrm{g} / \mathrm{mL}$ streptomycin were added $(1 \mathrm{~mL})$ to the wells at different concentrations [0.5 to $30 \mu \mathrm{M}$ with DMSO $1 \%$ (v/v)]. The plates were then incubated at $37{ }^{\circ} \mathrm{C}$ for $24 \mathrm{~h}$. Positive and negative controls included cells treated with reference drugs added at their corresponding $\mathrm{IC}_{50}$ (amphotericin B $0.27 \mu \mathrm{M}$ or potassium antimonyl tartrate trihydrate $15 \mu \mathrm{M})$ and DMSO at $1 \%(\mathrm{v} / \mathrm{v})$, respectively.
Each condition was tested at least in duplicates. Next, the coverslips were washed three times with phosphate buffered saline ( $\mathrm{pH} 7.0$ ), cells fixed with ethanol for $10 \mathrm{~min}$ and mounted on glass slides with fluoroshield $^{\mathrm{TM}}$-DAPI medium to stain nuclei. The relative number of infected macrophages was determined from the analysis of 200 cells distributed in 4 to 5 field, using an Olympus IX-81 inverted fluorescence microscope (emission filter $420-460 \mathrm{~nm}$ ). The percentage of infected macrophages (\% IM) by a compound $\mathrm{X}$ at concentration $\mathrm{Y}$ is calculated as follow: (relative number of infected macrophages treated with compound $\mathrm{X}$ at concentration $\mathrm{Y} /$ relative number of infected macrophages in the non-treated group) $\times 100$.

\subsubsection{Determination of minimal inhibitory concentration (MIC) against Mycobacterium tuberculosis $\mathrm{H}_{37} \mathrm{Rv}$}

The anti-MTB activity of the compounds was determined on the sensitive strain MTB $\mathrm{H}_{37} \mathrm{Rv}$ ATCC 27294 by the REMA (Resazurin Microtiter Assay) method [45]. Stock solutions of the tested compounds were prepared in DMSO and diluted in Middlebrook 7H9 broth (Difco) supplemented with oleic acid, albumin, dextrose and catalase (OADC enrichment - BBL/Becton-Dickinson), to obtain final drug concentration ranges of $0.09-25 \mu \mathrm{g} / \mathrm{mL}$. Isoniazid (INH) was dissolved in distilled water and rifampicin (RFP) in DMSO, and both were used as standard drugs. A suspension of MTB $\mathrm{H}_{37} \mathrm{Rv}$ ATCC 27294 was cultured in Middlebrook 7H9 broth supplemented with OADC and 0.05\% Tween 80 . After two days the $\mathrm{CFU} / \mathrm{mL}$ (colony formation unit/mL) of an aliquot was determined. The concentrations were adjusted by $5 \times 10^{5} \mathrm{CFU} / \mathrm{mL}$ 
and $100 \mu \mathrm{L}$ of the inoculum were added to each well of a 96-well microplate together with $100 \mu \mathrm{L}$ of the compounds. The plates were incubated for 7 days at $37^{\circ} \mathrm{C}$. Resazurin (solubilized in water) was added ( $30 \mu \mathrm{L}$ of $0.01 \%$ ). The fluorescence of the wells was read at $530 / 590 \mathrm{~nm}$ after $24 \mathrm{~h}$ with a Cytation 3 (Biotek $^{\circledast}$ ) equipment. The assays were performed in triplicate. The MIC were calculated from a calibration curve by regression analysis and it was defined as the lowest concentration resulting in $90 \%$ inhibition of growth of MTB.

\subsubsection{Activity on $M$. tuberculosis clinical isolates}

Activity on MTB clinical isolates was evaluated using the technique shown above. Clinical isolates were collected at the Clemente Ferreira Hospital in São Paulo city, Brazil, between 2007 and 2009. The epidemiological profile of these clinical strains, as well as resistance to INH and RFP, have been previously described $[46,47]$.

\subsubsection{Cytotoxicity on MRC-5 human lung cells}

The cell line used was MRC-5 (human lung fibroblast cell line-ATCC, CCL-171). Cytotoxicity of the compounds on MRC-5 human lung cells was evaluated according to a published procedure [48]. Cells were routinely maintained in complete medium supplemented with $10 \%$ fetal bovine serum (FBS) plus amphotericin B (2 mg/ $\mathrm{L})$ and gentamicin $(50 \mathrm{mg} / \mathrm{L})$ at $37{ }^{\circ} \mathrm{C}$ in a humidified $5 \% \mathrm{CO}_{2}$ atmosphere. For the cytotoxicity assay, $2.5 \times 10^{4}$ cells $/ \mathrm{mL}$ were seeded into a 96 -well cell culture plate with a total volume of $100 \mu \mathrm{L}$ for $24 \mathrm{~h}$. Cells were treated with compounds at concentrations ranging from 1 to $100 \mu \mathrm{M}$. After $24 \mathrm{~h}$ incubation, medium was removed, and $50 \mu \mathrm{L}$ of resazurin $(0.01 \% \mathrm{w} / \mathrm{v})$ was added to each well, and the plates were incubated at $37^{\circ} \mathrm{C}$ for $3 \mathrm{~h}$. Fluorescence of wells was measured on a Synergy H1 microplate reader (BioTek, Winooski, VT, USA) in which were used excitation $(530 \mathrm{~nm})$ and emission $(590 \mathrm{~nm})$ filters. The $\mathrm{IC}_{50}$ values were calculated from a calibration curve by regression analysis. Doxorubicin and untreated cells constituted the positive and negative controls, respectively. Three independents assays were performed. The Selectivity Index (SI) was calculated by dividing the $\mathrm{IC}_{50} / \mathrm{MIC}$ values [49].

\subsection{Lipophilicity studies}

Reversed-phase TLC experiments were performed on precoated TLC plates SIL RP-18 W/ $\mathrm{UV}_{254}$ and eluted with MeOH:DMF: $\mathrm{H}_{2} \mathrm{O}$ (65:5:30 v/ $\mathrm{v} / \mathrm{v}$ ). Stock solutions were prepared in pure dichloromethane (Aldrich) prior to use. The plates were developed in a closed chromatographic tank, dried and the spots were detected under UV light. The $R_{\mathrm{f}}$ values were averaged from two to three determinations, and converted to $R_{\mathrm{M}}$ via the relationship: $R_{\mathrm{M}}=\log _{10}\left[\left(1 / R_{\mathrm{f}}\right)-1\right][50-53]$.

\subsection{Insight into the mechanism of action}

\subsubsection{Intracellular thiol-redox state of infective T. brucei}

The potential interference of the compounds with thiol-redox homeostasis of African trypanosomes was investigated using a T. brucei cell line that allows for the tetracycline-inducible expression of the redox biosensor hGrx-roGFP2 [43,54]. Parasites grown to the exponential phase in the absence or presence of $1 \mu \mathrm{g} / \mathrm{mL}$ oxytetracycline were resuspended in fresh medium (Section 2.5.1) at a density of $5 \times 10^{5}$ cells $/ \mathrm{mL}$ and distributed in a 96 -well plate $(100 \mu \mathrm{L} /$ well $)$. Wells containing oxytet-induced parasites were added of compounds at concentrations corresponding to their $\mathrm{IC}_{50}$ values, the oxidant menadione $(125,250$ and $500 \mu \mathrm{M})$ or vehicle alone (DMSO $1 \% \mathrm{v} / \mathrm{v}$ ). Wells containing non-induced parasites and non-treated with compounds or menadione were included as control. The culture plates were incubated for $1 \mathrm{~h}$ and $3 \mathrm{~h}$ at $37^{\circ} \mathrm{C}$ and $5 \% \mathrm{CO}_{2}$, and then $50 \mu \mathrm{L}$ from each well were transferred to a 96 well u-bottom plate containing $100 \mu \mathrm{L}$ of sterile PBS with glucose $1 \%(\mathrm{w} / \mathrm{v})$. For menadione and, if any, compounds decreasing the mean intensity of roGFP2, a second sample was incubated with $1 \mathrm{mM}$ dithiotreitol (DTT, a cell permeant reducing agent) for 15 min prior to analysis by flow cytometry to confirm the redox basis of the change in biosensor's fluorescence. All samples were added of PI $(2 \mu \mathrm{g} / \mathrm{mL}$ ) immediately prior to data acquisition with a C6Accuri flow cytometer (BD). GFP fluorescence (filter $\lambda_{\mathrm{em}}=530 / 40 \mathrm{~nm}$ ) was measured only for viable cells (PI negative). The data were processed and analyzed with the C6Accuri software.

\subsubsection{DNA interaction by fluorescence studies}

Experiments for competitive binding to calf thymus DNA (ctDNA, SIGMA, Type I, No. D-1501) with ethidium bromide (EB, SIGMA) were carried out in $10 \mathrm{mM}$ Tris- $\mathrm{HCl}$ buffer at $\mathrm{pH}$ 7.4. Millipore ${ }^{\circledR}$ water was used for the preparation of all aqueous solutions. Fluorescence measurements were carried out on individually prepared samples to ensure the same pre-incubation time for all samples in each assay. Due to the low solubility of the complexes in aqueous media, DMSO was used to prepare concentrated stock solutions followed by appropriate dilution to obtain the targeted concentration and the same content of DMSO $(5 \% \mathrm{v} / \mathrm{v})$ in the final samples. DNA stock solutions were prepared by hydrating ctDNA in Tris-HCl buffer $\left(1 \mathrm{mg} / \mathrm{mL}, \sim 2 \mathrm{mM} \mathrm{nuc}^{-1}\right)$ by gently stirring the solution during 2-3 days. This solution was stored at $4{ }^{\circ} \mathrm{C}$ (in the fridge) in-between measurements. The concentration of the stock solution was determined by UV spectrophotometry using the molar absorption coefficient $\varepsilon(260 \mathrm{~nm})=6600 \mathrm{M}^{-1} \mathrm{~cm}^{-1}$ nuc ${ }^{-1}$ [55]. An EB $5 \mathrm{mM}$ solution was prepared in Tris-HCl buffer. ctDNA was pre-incubated with EB at $4{ }^{\circ} \mathrm{C}$ for $24 \mathrm{~h}$. Samples were prepared with a total concentration of DNA and of $\mathrm{EB}$ of $20 \mu \mathrm{Mnuc}^{-1}$ and $10 \mu \mathrm{M}$, respectively, varying the total complex concentration from 5 to $70 \mu \mathrm{M}$. They were incubated at $37^{\circ} \mathrm{C}$ for $30 \mathrm{~min}$. Samples with complex alone, samples with complex and DNA and samples with complex and EB but no DNA were used as blanks. Fluorescence spectra were recorded from $520 \mathrm{~nm}$ to $630 \mathrm{~nm}$ at an excitation wavelength of $510 \mathrm{~nm}$ on a Infinite M200 PRO TECAN plate spectrofluorimeter.

\section{Results and discussion}

Four new organometallic heterobimetallic compounds of the HTrop and HHino ligands with the formulas $[\mathrm{M}(\mathrm{Trop})(\mathrm{dppf})]\left(\mathrm{PF}_{6}\right)$ and $[\mathrm{M}$ (Hino)(dppf)] $\left(\mathrm{PF}_{6}\right)$, where $\mathrm{M}=\mathrm{Pd}(\mathrm{II})$ or $\mathrm{Pt}(\mathrm{II})$, were obtained with high purities and good yields and they were exhaustively characterized in the solid state and in solution.

\subsection{Characterization in the solid state}

\subsubsection{IR spectroscopic characterization}

Most relevant IR vibration bands of the four complexes were assigned taking into account previous assignments performed on tropolone, hinokitiol and dppf metal compounds (Tables S1 and S2) [37,56-58].

For free HTrop, it has been demonstrated that although $\nu(C=C)$ and $\nu(\mathrm{C}=\mathrm{O})$ vibrations are strongly coupled, leading to two strong bands at 1612 and $1547 \mathrm{~cm}^{-1}$, the higher energy band has more $v(\mathrm{C}=\mathrm{C})$ character. After complex formation both bands were displaced to lower energies in both Trop complexes (Table S2). The strong coupled $\nu(\mathrm{C}=$ $\mathrm{O})+v(\mathrm{C}=\mathrm{C})+\delta(\mathrm{C}-\mathrm{H})$ band at $1478 \mathrm{~cm}^{-1}$ and the strong $v(\mathrm{C}-\mathrm{O})$ doublet were also displaced to lower energies in the new compounds, as previously reported for other complexes [58].

A similar spectroscopic pattern was observed for the Hino complexes (Table S2). In addition, three weak characteristic signals of the isopropyl group were also identified in the $2865-2965 \mathrm{~cm}^{-1}$ region of the spectra of both Hino complexes [37,56]. As expected the medium intensity $\nu(\mathrm{OH})$ vibration of both free ligands around $3200 \mathrm{~cm}^{-1}$ are absent in the four complexes due to deprotonation of the ligands. The typical five signals pattern of the dppf moiety and both strong signals of the hexafluorophosphate anion were also identified in the spectra of the four new complexes $[59,60]$. 


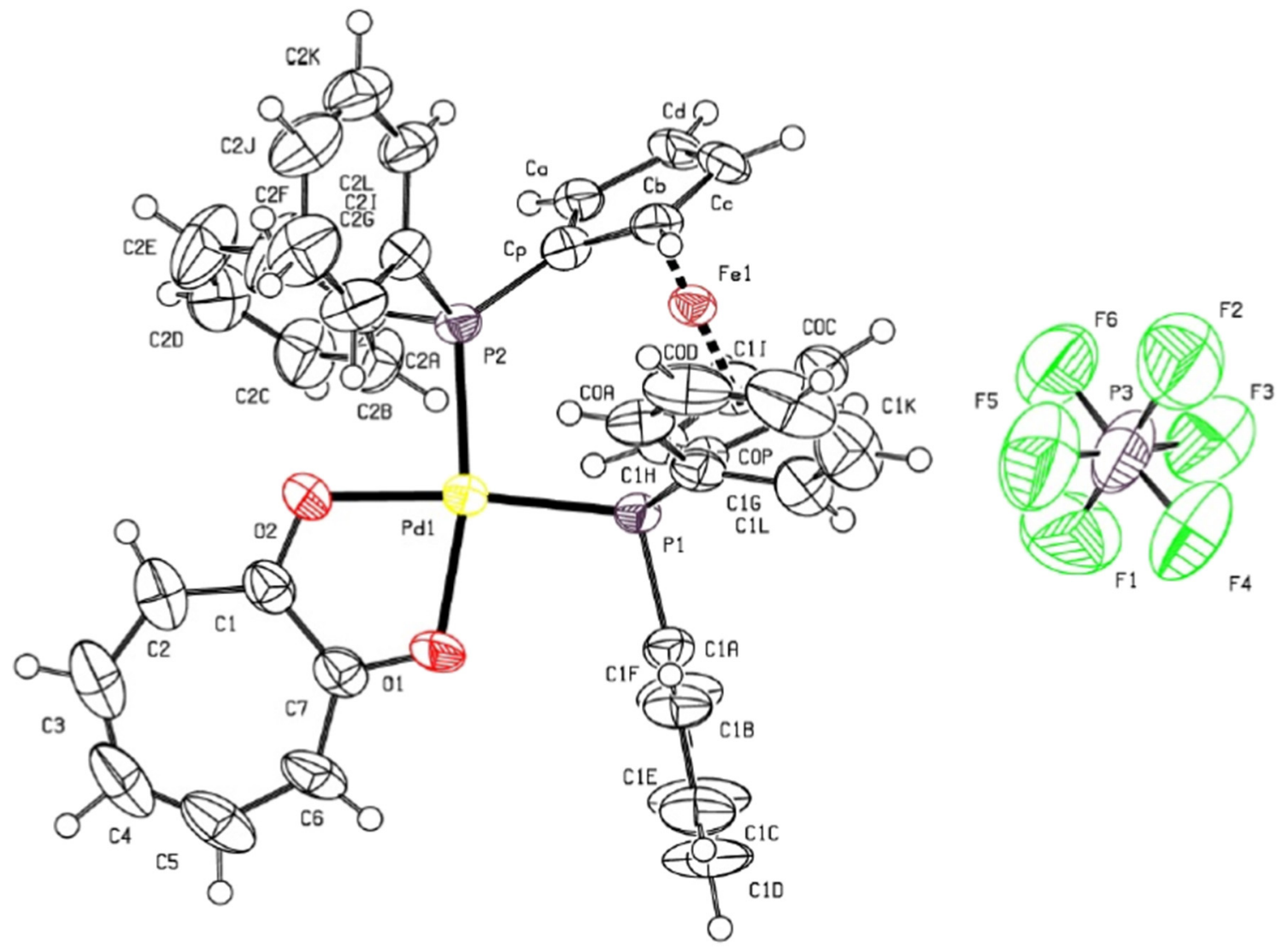

Fig. 2. Drawing of the palladium(II) complex in the $[\mathrm{Pd}(\mathrm{Trop})(\mathrm{dppf})]\left(\mathrm{PF}_{6}\right)$ solid showing the atomic displacement ellipsoids at the $50 \%$ probability level.

3.1.2. Crystal structure of isomorphous $\left[M^{I I}(T r o p)(d p p f)\right]\left(P F_{6}\right)$ and $\left[M^{I I}\right.$ (Hino) $($ dppf $\left.)\right]\left(P_{6}\right)$ complexes $(M=P d$ or $P t)$

Single crystals of $[\mathrm{M}(\mathrm{Trop})(\mathrm{dppf})]\left(\mathrm{PF}_{6}\right)$ and $[\mathrm{M}(\mathrm{Hino})(\mathrm{dppf})]\left(\mathrm{PF}_{6}\right)$, where $\mathrm{M}=\mathrm{Pd}(\mathrm{II})$ or $\mathrm{Pt}(\mathrm{II})$, suitable for X-ray diffraction studies, were obtained by slow diffusion of hexane into a dichloromethane solution of the compounds. Figs. 2 and S1 show the ORTEP drawings of the tropolone and hinokitiol palladium complexes, respectively. Intra-molecular bond distances and angles around the metal of the four complexes are given in Table 2 .

The compounds crystallize in the monoclinic $P 2_{1} / c$ space group. The central metal ions are in a nearly planar trapezoidal environment, ciscoordinated to a tropolone or hinokitiol molecule acting as a bidentate ligand through the two oxygen atoms, and to the $1,1^{\prime}$-bis (diphenylphosphino)ferrocene molecule acting as a bidentate ligand through its phosphorous atoms. The deviation of atoms from the best least squares

Table 2

Bond lengths $(\AA)$ and angles $\left(^{\circ}\right)$ around the metal center in [M(Trop)(dppf)] $\left(\mathrm{PF}_{6}\right)$ and $[\mathrm{M}(\mathrm{Hino})(\mathrm{dppf})]\left(\mathrm{PF}_{6}\right)$ complexes.

\begin{tabular}{|c|c|c|c|c|}
\hline & Pd-dppf-Trop & Pt-dppf-Trop & Pd-dppf-Hino & Pt-dppf-Hino \\
\hline \multicolumn{5}{|c|}{ Bond lengths (Å) } \\
\hline M-O1 & $2.064(4)$ & $2.072(3)$ & $2.033(3)$ & $2.055(2)$ \\
\hline M-O2 & 2.047 (4) & $2.081(3)$ & $2.047(3)$ & $2.052(2)$ \\
\hline M-P1 & $2.244(1)$ & $2.2383(9)$ & $2.256(1)$ & $2.2474(7)$ \\
\hline M-P2 & $2.255(1)$ & $2.2301(9)$ & $2.2656(9)$ & $2.2362(7)$ \\
\hline \multicolumn{5}{|c|}{ Bond angles $\left({ }^{\circ}\right)$} \\
\hline O2-M-P1 & $173.4(1)$ & $173.06(8)$ & $171.39(8)$ & $170.33(7)$ \\
\hline O2-M-P2 & $88.2(1)$ & $87.87(8)$ & $91.66(9)$ & $92.06(7)$ \\
\hline O2-M-O1 & $79.6(2)$ & $79.6(1)$ & $79.7(1)$ & $78.83(9)$ \\
\hline P1-M-P2 & $98.37(5)$ & $99.04(3)$ & $97.09(4)$ & $97.47(3)$ \\
\hline O1-M-P1 & $94.0(1)$ & $93.63(8)$ & $91.52(8)$ & $91.63(6)$ \\
\hline O1-M-P2 & $166.3(1)$ & $166.20(8)$ & $170.9(1)$ & $170.88(6)$ \\
\hline
\end{tabular}

plane is quite higher for the Pd compounds than for the analogous $\mathrm{Pt}$ compounds, rms: Pd-dppf-Trop 0.063; Pt-dppf-Trop 0.057; Pd-dppfHino 0.021; Pt-dppf-Hino $0.012 \AA$. These values confirm a higher tendency of the Pd compounds to distort their coordination environment.

$[\mathrm{M}(\mathrm{Trop})(\mathrm{dppf})]\left(\mathrm{PF}_{6}\right)$ structures show $\mathrm{M}-\mathrm{O}$ distances in the same range observed in other complexes with the Trop ligand (Pd-O1: 2.064(4) ^, Pd-O2: 2.047(4) $\AA$ and Pt-O1: 2.072(3) A, Pt-O2: $2.081(3) \AA)[56,61]$. The same behavior was observed for the hinokitiol complexes (Pd-O1: 2.033(3) ̊, Pd-O2: 2.047(3) $\AA$ and Pt-O1: 2.055(3) §, Pt-O2: 2.052(3) ̊) [37,56,62]. In the four complexes, the dppf ligand showed the expected archimidean pentagonal anti-prism conformation for the coordination around the iron in the ferrocene fragment, with the $\mathrm{Cp}$ rings staggered to each other [29]. The Fe-C distances range from 2.012 to $2.081 \AA$ in the tropolone complexes and from 2.002 to $2.064 \AA$ in the hinokitiol compounds. The M-P distances lie also in the normal ranges observed in others complexes with the bidentate ligand dppf (see Table 2) [29]. Crystallographic structural data have been deposited at the Cambridge Crystallographic Data Centre (CCDC). Any request to the CCDC for this material should quote the full literature citation and the reference number CCDC 1854159 for $\left[\mathrm{Pd}^{\mathrm{II}}\right.$ (Trop)(dppf)]( $\left.\mathrm{PF}_{6}\right)$, CCDC 1854161 for $\left[\mathrm{Pt}^{\mathrm{II}}(\mathrm{Trop})(\mathrm{dppf})\right]\left(\mathrm{PF}_{6}\right)$, CCDC 1854158 for [Pd $\left.{ }^{\mathrm{II}}(\mathrm{Hino})(\mathrm{dppf})\right]\left(\mathrm{PF}_{6}\right)$ and CCDC 1854160 for $\left[\mathrm{Pt}^{\mathrm{II}}(\right.$ Hino $\left.)(\mathrm{dppf})\right]\left(\mathrm{PF}_{6}\right)$.

\subsection{Characterization in solution}

Conductivity measurements of DMSO $10^{-3} \mathrm{M}$ solutions led to molar conductivity values $\left(\approx 25 \mathrm{Scm}^{2} / \mathrm{mol}\right)$ in the range reported for $1: 1$ electrolytes, in agreement with the proposed structures [39]. No conductivity changes were observed during at least 7 days at $25^{\circ} \mathrm{C}$. In addition, neither changes in intensity of the signals nor new peaks due to release of free ligands were detected in ${ }^{1} \mathrm{H}$ NMR spectra followed with time. Hence both results suggest that the complexes are stable in 


\begin{tabular}{|c|c|c|c|c|c|c|c|c|c|c|}
\hline & dppf & & HTr & & & $\sum_{8}^{4}$ & & & & \\
\hline \multirow[t]{2}{*}{$\mathrm{H}$} & \multicolumn{10}{|c|}{$\delta_{\mathrm{H}}$ (multiplicity) (integration) } \\
\hline & HTrop & Pd-Trop-dppf & $\Delta \delta^{\mathrm{a}}$ & Pt-Trop-dppf & $\Delta \delta^{\mathrm{a}}$ & HHino & Pd-Hino-dppf & $\Delta \delta^{\mathrm{a}}$ & Pt-Hino-dppf & $\Delta \delta^{\mathrm{a}}$ \\
\hline 7 & d & $\mathrm{d}$ & -0.32 & $\mathrm{~d}$ & -0.12 & 7.10 (d) (1) & 7.20 (d) (1) & 0.10 & 7.42 (d) (1) & 0.32 \\
\hline 8 & - & - & - & - & - & $2.89(\mathrm{sp})(1)$ & $2.83(\mathrm{br})(1)$ & -0.06 & $2.91(\mathrm{~m})(1)$ & 0.02 \\
\hline 9 & - & - & - & - & - & 1.20 (d) (6) & 1.10 (d) (6) & -0.10 & 1.12 (d) (6) & -0.08 \\
\hline 10 & - & - & - & - & - & & & & & \\
\hline $\mathrm{H}_{\mathrm{a}}$ & - & $4.54(\mathrm{~s})(4)$ & 0.56 & 4.45 (s) (4) & 0.47 & - & $4.58(s)^{\mathrm{c}}$ & 0.64 & $4.67(\mathrm{~s})(2)$ & 0.69 \\
\hline $\mathrm{H}_{\mathrm{b}}$ & \multirow{3}{*}{-} & \multirow{3}{*}{$4.74(\mathrm{~s})(4)$} & \multirow{3}{*}{0.47} & \multirow{3}{*}{4.69 (s) (4) } & \multirow{3}{*}{0.42} & & $4.74(s)^{c}$ & 0.80 & $4.71(\mathrm{~s})(2)$ & 0.73 \\
\hline $\mathrm{H}_{\mathrm{c}}$ & & & & & & \multirow[t]{2}{*}{-} & $4.53(s)^{\mathrm{c}}$ & 0.26 & $4.54(\mathrm{~s})(2)$ & 0.27 \\
\hline $\mathrm{H}_{\mathrm{d}}$ & & & & & & & $4.28(\mathrm{~s})^{\mathrm{c}}$ & 0.01 & 4.35 (s) (2) & 0.08 \\
\hline
\end{tabular}

Multiplicity: s: singlet, d: doublet, t: triplet, sp: septuplet, m: multiplet, br: broad.

a $\Delta \delta: \delta_{\text {complex }}-\delta_{\text {ligand }}$.

b Overlapped with $\mathrm{PPh}_{2}$ protons signals.

c Four broad signals are observed and altogether they integrate for eight protons.

d Protons 3 and 7 show the same chemical shift in HTrop and its complexes, integrating the signal for two protons. The same happens for protons 4 and 6 [63].

DMSO solution.

\subsubsection{NMR results}

${ }^{1} \mathrm{H}$ NMR spectra were recorded to completely characterize the obtained complexes in DMSO- $d_{6}$ solution. Two-dimensional COSY NMR experiments aided in the assignment of the spectra. Results of the experiments for the ligands and the complexes are shown in Table 3.

As expected, the four complexes showed a similar pattern of signals corresponding to the protons of the tropolone, hinokitiol and dppf ligands. Obtained integrations and multiplicities of the signals are in accordance with the obtained stoichiometry of the complexes. In the region of 6-8 ppm signals of the protons of the free ligands and of the phosphine substituents of dppf were observed and assigned. Because of metal coordination, the signals of the protons of Trop and Hino shifted. The ${ }^{1} \mathrm{H}$ NMR spectrum of tropolone shows a doublet at $7.22 \mathrm{ppm}$ assigned to protons 3 and 7 (Table 3) [63]. Due to the closeness of these protons to the metal center, this doublet shifts significantly to higher fields after coordination [64]. A similar behavior was observed for proton 3 of the hinokitiol complexes [56,65].

Two proton signals (singlets, four proton integration) at 3.94 and 4.27 ppm were observed for the $\mathrm{Cp}$ rings of the dppf free ligand. These signals have been assigned to equivalent $\mathrm{H}_{\mathrm{a}}-\mathrm{H}_{\mathrm{b}}$ and $\mathrm{H}_{\mathrm{c}}-\mathrm{H}_{\mathrm{d}}$ protons of both $\mathrm{Cp}$ rings that are coplanar to each other and appear like an average eclipsed conformation at room temperature (Table 3) [66]. A similar two signals pattern was observed for both M-dppf-Trop complexes. This behavior has been previously observed for other M-dppf complexes with bidentate ligands [67]. On the other hand, in the new hinokitiol metal compounds, these two signals split into four. The equivalence of the $\mathrm{Cp}$ protons is broken under formation of the M-dppf-Hino complexes due to the loss of fluxionality probably generated by the increased steric hindrance arisen by the presence of the isopropyl substituent in the bidentate Hino ligand $[68,69]$. A similar splitting into four signals corresponding to both $\mathrm{Cp}$ rings in the ferrocene moiety was observed for analogous $[\mathrm{M}(\mathrm{mpo})(\mathrm{dppf})]\left(\mathrm{PF}_{6}\right)$, where $\mathrm{M}=\mathrm{Pd}(\mathrm{II})$ or $\mathrm{Pt}$ (II) and Hmpo is the bioactive ligand pyridine-2-thiol 1-oxide [29].

At higher ppm values, multiplets corresponding to the protons of the $\mathrm{PPh}_{2}$ moieties of the dppf ligand were also observed. The $\mathrm{PPh}_{2}$ moieties of free dppf lead to two singlets [7.22 (s) (8) and 7.33 (s) (12)]. For the four M-dppf complexes these signals split into multiplets integrating globally for 20 protons and shift to higher chemical displacements [29].

\subsection{Biological results}

\subsubsection{Anti-T. brucei activity and selectivity towards the parasite}

The anti-trypanosomal activity of the different heterobimetallic ferrocenyl derivatives and the corresponding ligands (dppf, HHino and HTrop) was evaluated against the bloodstream form of T. brucei. The results are presented in Table 4.

The free ligands dppf and HTrop lacked anti-parasitic activity when tested at $10 \mu \mathrm{M}$ (note: higher concentrations could not be tested due to the poor solubility of the compound in the parasite culture medium) and $60 \mu \mathrm{M}$, respectively. In contrast, the $\mathrm{IC}_{50}$ of HHino $(27 \mu \mathrm{M})$ was higher than that of the reference anti-trypanosomal drug Nifurtimox $\left(\mathrm{IC}_{50}=15 \mu \mathrm{M}\right)$. Noticeably, the complexation of these ligands to Mdppf co-ligand increased significantly their anti-trypanosomal activity yielding $\mathrm{IC}_{50}$ values $<5 \mu \mathrm{M}$. The highest difference corresponded to the HTrop ligand, which increased its activity by $>28$ - and $>46$-fold when coordinated to $\{\mathrm{Pt}-\mathrm{dppf}\}$ and $\{\mathrm{Pd}-\mathrm{dppf}\}$, respectively. Similarly, the complexation of M-dppf to Hino increased by 6- and 22-fold, respectively, the activity of the ligand. This comparison also highlights that the Pd complexes $\left(\mathrm{IC}_{50}\right.$ values from 1.2 to $1.3 \mu \mathrm{M}$ ) are slightly more cytotoxic (1.6- to 3.8-fold) towards parasites than those based on Pt 
Table 4

In vitro activity against infective stages of trypanosomatids and J774 murine macrophages, selectivity index (SI) values and lipophilicity of [M(Trop)(dppf)] $\left(\mathrm{PF}_{6}\right),[\mathrm{M}(\mathrm{Hino})(\mathrm{dppf})]\left(\mathrm{PF}_{6}\right)$ complexes and HTrop, HHino and dppf (included for comparison).

\begin{tabular}{|c|c|c|c|c|c|c|}
\hline \multirow[t]{2}{*}{ Compound } & \multicolumn{2}{|l|}{$\mathrm{IC}_{50}(\mu \mathrm{M})$} & \multirow[t]{2}{*}{$\mathrm{SI}^{\mathrm{a}}$} & \multirow{2}{*}{$\begin{array}{l}\% \mathrm{IM}^{\mathrm{b}} \\
5 \mu \mathrm{M} L . \\
\text { infantum }\end{array}$} & \multirow[t]{2}{*}{$R_{f}$} & \multirow[t]{2}{*}{$R_{M}$} \\
\hline & T. brucei-GFP & Macrophages & & & & \\
\hline dppf & $>10$ & $45 \pm 6$ & $<4$ & $82 \pm 14$ & ND & ND \\
\hline HHino & $27 \pm 2$ & $>100$ & $>4$ & $75 \pm 7$ & 0.72 & -0.41 \\
\hline HTrop & $>60$ & $67 \pm 13$ & $\sim 1$ & $65 \pm 5$ & 0.87 & -0.81 \\
\hline Pd-dppf-Trop & $1.3 \pm 0.1$ & $10 \pm 1$ & 8 & $50 \pm 3$ & 0.11 & 0.93 \\
\hline Pt-dppf-Trop & $2.1 \pm 0.1$ & $38.7 \pm 0.1$ & 18 & $55 \pm 4$ & 0.15 & 0.76 \\
\hline Pd-dppf-Hino & $1.2 \pm 0.1$ & $3.2 \pm 0.5$ & 3 & $69 \pm 8$ & 0.09 & 1.02 \\
\hline Pt-dppf-Hino & $4.5 \pm 0.1$ & $>100$ & $>22$ & $68 \pm 3$ & 0.10 & 0.95 \\
\hline Nifurtimox & $15 \pm 3^{c}$ & $150 \pm 5^{\mathrm{d}}$ & 10 & ND & ND & ND \\
\hline
\end{tabular}

a SI, selectivity index ( $\mathrm{IC}_{50} \mathrm{J774}$ murine macrophages / $\mathrm{IC}_{50}$ T. brucei $)$.

b \% IM, relative percentage of infected macrophages treated with the corresponding compound vs. non-treated and infected macrophages.

${ }^{c} R_{\mathrm{f}}$ and $R_{\mathrm{M}}$ values (lipophilicity) obtained using reversed phase TLC and $\mathrm{MeOH}:$ DMF: $\mathrm{H}_{2} \mathrm{O}$ (65:5:30 v/v/v) as mobile phase.

d Data from [71] ND: not determined.

( $\mathrm{IC}_{50}$ values from 2.1 to $4.5 \mu \mathrm{M}$ ). In addition, all Pd complexes proved to be about 10 -fold more potent than Nifurtimox.

In order to get further insight into the biological selectivity of the four metal compounds, their cytotoxicity against macrophages (J774 murine cell line) was tested (Table 4). Macrophages play important roles in controlling trypanosomiasis and are highly sensitive to environmental factors, including xenobiotics, and are the host cells colonized by Leishmania (see next section) [70]. Among the free ligands, dppf ( $\mathrm{IC}_{50} 45 \mu \mathrm{M}$ ) and HTrop ( $\mathrm{IC}_{50} 67 \mu \mathrm{M}$ ) present a quite similar toxicity against macrophages, whereas HHino lacks toxic effect even at $100 \mu \mathrm{M}$. Independently of the ligand, complexation to \{Pd-dppf $\}$ increased the cytotoxicity of the derivatives with respect to the free ligands following the order Pd-dppf-Hino ( $>30$-fold cytotoxic) $>$ Pddppf-Trop ( $>$ 6.7-fold cytotoxic). In contrast, the coordination to Pt had more scattered effects on the cytotoxicity towards macrophages. For instance, while Pt-dppf-Trop was 1.7-fold more toxic than the free ligand, coordination of Hino to Pt-dppf moiety did not modify the biological effect or even decreased the toxicity, respectively.

Estimation of the selectivity index (SI $=\mathrm{IC}_{50}$ macrophage vs. $\mathrm{IC}_{50} T$. brucei) for each compound showed that the ligands alone lack specificity towards killing trypanosomes as their SI ( 1 to $>4)$ were below that of Nifurtimox $(\mathrm{SI}=10)$. As expected from the cytotoxicity observed against macrophages, the complexes of Pd with Hino (SI $=3$ ) and Trop $(\mathrm{SI}=8)$ rendered low SI values. In contrast, the Pt-derivatives of Hino and Trop presented SI (SI from 18 to $>23$ ) higher than the Pd analogues and than Nifurtimox.

The Special Programme for Research and Training in Tropical Diseases (TDR), which is leading research on discovery against neglected diseases, considers a drug hit for HAT a compound presenting an $\mathrm{IC}_{50}$ of $\leq 0.2 \mu \mathrm{g} / \mathrm{mL}$ against whole organism and a selectivity index SI $>100$ [72]. Although these new Pt compounds did not accomplish both criteria, they showed low $\mathrm{IC}_{50}$ values and fairly good SI values and can be considered promising compounds for further drug development.

\subsubsection{Activity on L. infantum amastigotes}

In order to get an insight into a potential broad activity of the derivatives against trypanosomatid parasites, they were tested against the intracellular form (amastigote) of the trypanosomatid L. infantum, which naturally colonizes macrophages when infecting mammals.

At concentrations $<5 \mu \mathrm{M}$ none of the compounds was effective in inhibiting macrophage infection by L. infantum (not shown). This, together with the plateau in anti-leishmanial activity observed for most compounds at concentrations between 5 and $20 \mu \mathrm{M}$, did not allow us to estimate $\mathrm{IC}_{50}$ values from drug-response curves. At $5 \mu \mathrm{M}$ all free ligands displayed a low capacity to inhibit macrophage infection with HTrop (65\% IM) and HHino (75\% IM) being the most active. Although the data obtained for dppf display a large degree of dispersion, this ligand is clearly no more active than HTrop (Table 4). At variance with the significant improvement observed in the anti- $T$. brucei activity of the metal complexes, incorporation of the Pt-dppf co-ligand did have a slight ( $\leq 1.3$-fold for the Hino and Trop complexes) impact on the antileishmanial potency of the ligands (Table 4). The activity of the M-dppfTrop compounds did not change substantially when concentration increased (data not shown). In contrast, the anti-leishmanial activity of the Hino complexes increased, although not proportionally, to higher concentrations. For instance, the IM at $20 \mu \mathrm{M}$ was $56 \%$ for Pd-dppfHino and $28 \%$ for Pt-dpf-Hino. Nonetheless, the anti-leishmanial activity of all the derivatives synthetized in this work is at least two orders of magnitude lower than that exhibited by the control drug amphotericin B. Assuming that their $\mathrm{IC}_{50}$ values are close to $5 \mu \mathrm{M}$ (Table 4 ), an apparent SI against L. infantum of 2 and 8 could be estimated for Pddppf-Trop and Pt-dppf-Trop, respectively. The $\mathrm{IC}_{50}$ values for Pd-dppfHino and Pt-dppf-Hino are likely close to $20 \mu \mathrm{M}$, which yields apparent SI values of 0.15 and $>5$, respectively. Overall, these estimations corroborate the poor selectivity of the Pd-dppf-Trop and Pd-dppf-Hino derivatives against $L$. infantum while highlighting that all Pt complexes are more effective in killing $T$. brucei than $L$. infantum.

\subsubsection{Activity on M. tuberculosis $H_{37} R v$ ATCC 27294 and on MTB clinical isolates and selectivity towards $M T B$}

The M-dppf-Trop and M-dppf-Hino compounds were more active on MTB $\mathrm{H}_{37} \mathrm{Rv}$ ATCC 27294 (pan-susceptible) than the free ligands, showing $\mathrm{MIC}_{90}$ values in the range 9.8-14.7 $\mu \mathrm{M}$ (Table 5).

With respect to their selectivity towards MTB, although the new Pd and Pt compounds showed nearly acceptable $\mathrm{MIC}_{90}$ values according to international guidelines (Table 5), they displayed a low specificity towards the mycobacteria. In fact, the SI values calculated against the MRC-5 human lung fibroblasts were $\leq 1$. Usually a compound is considered promising for further testing against $M$. tuberculosis if a SI value close or higher than 10 is found [73]. None of the new compounds

Table 5

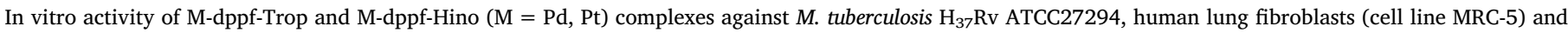
murine macrophages (cell line J774).

\begin{tabular}{|c|c|c|c|c|c|c|}
\hline Compound & $\mathrm{MIC}_{90}(\mu \mathrm{g} / \mathrm{mL})$ & $\mathrm{MIC}_{90}(\mu \mathrm{M})$ & MRC-5 IC $50(\mu \mathrm{M})$ & $\mathrm{SI}^{\mathrm{a}}$ & $\mathrm{J}_{774} \mathrm{IC}_{50}(\mu \mathrm{M})$ & $\mathrm{SI}^{\mathrm{b}}$ \\
\hline dppf & $>25.1$ & $>45.2$ & $>100$ & $\sim 2$ & $45 \pm 6$ & $<1$ \\
\hline HHino & $5.8 \pm 0.2$ & $35.4 \pm 1.5$ & $>100$ & $>3$ & $>100$ & $>3$ \\
\hline HTrop & $3.5 \pm 1.3$ & $29.0 \pm 1.1$ & $>100$ & $>3$ & $67 \pm 13$ & 2 \\
\hline Pd-dppf-Trop & $9.1 \pm 2.3$ & $9.0 \pm 2.5$ & $11.4 \pm 1.6$ & 1 & $10 \pm 1$ & 1 \\
\hline Pt-dppf-Trop & $17.0 \pm 4.2$ & $17.6 \pm 4.1$ & $18.4 \pm 0.6$ & 1 & $38.7 \pm 0.1$ & 2 \\
\hline Pd-dppf-Hino & $13.9 \pm 7.4$ & $13.1 \pm 7.6$ & $9.3 \pm 0.3$ & 0.7 & $3.2 \pm 0.5$ & 0.2 \\
\hline Pt-dppf-Hino & $15.6 \pm 4.7$ & $14.7 \pm 4.4$ & $13.5 \pm 1.3$ & 0.9 & $>100$ & 7 \\
\hline
\end{tabular}

$\mathrm{SI}^{\mathrm{a}}=\mathrm{IC}_{50 \text { MRC-5cells }} / \mathrm{MIC}_{90}$.

$\mathrm{SI}^{\mathrm{b}}=\mathrm{IC}_{50} \mathrm{~J} 774$ cells $/ \mathrm{MIC}_{90}$. 
Table 6

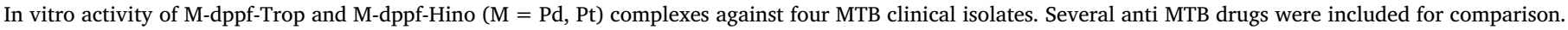

\begin{tabular}{|c|c|c|c|c|c|c|c|c|}
\hline & \multicolumn{2}{|l|}{ CF 93} & \multicolumn{2}{|l|}{ CF 100} & \multicolumn{2}{|l|}{ CF 112} & \multicolumn{2}{|l|}{ CF 169} \\
\hline & $\mathrm{MIC}_{90}(\mu \mathrm{g} / \mathrm{mL})$ & $\mathrm{MIC}_{90}(\mu \mathrm{M})$ & $\mathrm{MIC}_{90}(\mu \mathrm{g} / \mathrm{mL})$ & $\mathrm{MIC}_{90}(\mu \mathrm{M})$ & $\mathrm{MIC}_{90}(\mu \mathrm{g} / \mathrm{mL})$ & $\mathrm{MIC}_{90}(\mu \mathrm{M})$ & $\mathrm{MIC}_{90}(\mu \mathrm{g} / \mathrm{mL})$ & $\mathrm{MIC}_{90}(\mu \mathrm{M})$ \\
\hline dppf & $>25.00$ & $>45.10$ & $>25.00$ & $>45.10$ & $>25.00$ & $>45.10$ & $>25.00$ & $>45.10$ \\
\hline HHino & $>25.00$ & $>152.25$ & 14.42 & 87.82 & $>25.00$ & $>152.25$ & $>25.00$ & $>152.25$ \\
\hline HTrop & 4.96 & 40.61 & 2.23 & 18.30 & 12.14 & 99,44 & $>25.00$ & $>204.72$ \\
\hline Pd-dppf-Trop & 23.74 & 25.64 & 8.38 & 9.05 & $>25.00$ & $>26,99$ & $>25.00$ & $>26,99$ \\
\hline Pt-dppf-Trop & $>25.00$ & $>24.62$ & $>25.00$ & $>24.62$ & $>25.00$ & $>24.62$ & $>25.00$ & $>24.62$ \\
\hline Pd-dppf-Hino & 24.47 & 25.27 & $>25.00$ & $>25.83$ & $>25.00$ & $>25.83$ & $>25.00$ & $>25.83$ \\
\hline Pt-dppf-Hino & $>25.00$ & $>23.64$ & $>25.00$ & $>23.64$ & $>25.00$ & $>23.64$ & $>25.00$ & $>23.64$ \\
\hline Rifampicin & $>25.00$ & $>30.38$ & 0.36 & 0.43 & 6.51 & 7.91 & $>25.00$ & $>30.38$ \\
\hline Isoniazid & $>25.00$ & $>182.30$ & $>25.00$ & $>182.30$ & $>25.00$ & $>182.30$ & $>25.00$ & $>182.30$ \\
\hline Amikacin & 1.51 & 2.57 & $>25.00$ & $>42.69$ & 5.23 & 8.94 & $>25.00$ & $>42.69$ \\
\hline Streptomycin & 0.64 & 1.10 & $>25.00$ & $>42.99$ & 1.85 & 3.19 & 16.85 & 28.97 \\
\hline Ofloxacin & 0.57 & 1.59 & 6.05 & 16.74 & 11.84 & 32.75 & 7.25 & 20.06 \\
\hline Kanamycin & 3.05 & 6.29 & 18.52 & 38.22 & 5.19 & 10.72 & 9.58 & 19.77 \\
\hline Moxifloxacin & 0.11 & 0.27 & 3.11 & 7.74 & 1.11 & 2.76 & 2.15 & 5.36 \\
\hline Gatifloxacin & 0.75 & 1.98 & 4.43 & 11.80 & 0.66 & 1.75 & 10.05 & 26.78 \\
\hline
\end{tabular}

accomplished this criterion.

In addition, the compounds were tested on clinical isolates resistant against different antimicrobial drugs used to treat the disease (Table 6). CF93 is a MDR-TB (Multidrug-resistant TB) strain that does not respond to isoniazid and rifampicin, the two most powerful anti -TB drugs. The CF100 isolate is resistant to isoniazid, aminoglycosides and fluoroquinolones and is the only rifampicin-sensitive strain of the four strains tested. CF112 and CF169 correspond to XDR-TB (extensively drug-resistant TB); both being resistant to at least four of the core antiTB drugs.

Overall, the activity of the compounds against the clinical strains was lower than against the sensitive strain (H37Rv) (Table 6). For instance, the HHino ligand and its Pd-dppf and Pt-dppf derivatives exhibited activity against the sensitive strain (H37Rv) but proved inactive against the resistant strains. Among all compounds tested, HTrop and Pd-dppf-Trop represented the most active derivatives against the triple resistant TB strain CF100, confirming their anti-TB potential.

\subsection{Lipophilicity}

Lipophilicity is a very important physicochemical property that controls biological behavior, particularly transmembrane transport and interaction with biological receptors of a drug. Therefore, the correlation of lipophilicity with the observed biological activity of a prospective drug could be relevant [74]. The effect of complexation of HTrop and HHino on lipophilicity was experimentally determined using reversed-phase TLC, where the stationary phase (precoated TLC-C18) may be considered to simulate lipids of biological membranes or receptors, and the mobile phase (MeOH: DMF: $\left.\mathrm{H}_{2} \mathrm{O}(65: 5: 30 \mathrm{v} / \mathrm{v} / \mathrm{v})\right)$ resembles the aqueous biological milieu. The composition of the mobile phase was tuned-up in order to allow to differentiate complexes and free tropolones according to their lipophilicity. Results of measured $R_{f}$ and resulting $R_{M}$ value are shown in Table 4. As expected, the lipophilicity increased from the free ligand to its M-dppf compounds due to the inclusion of the $\{\mathrm{M}-\mathrm{dppf}\}$ moiety and HHino and their complexes are more lipophilic than HTrop and their complexes. No direct correlation between lipophilicity and activity on $T$. brucei could be observed. Lipophilicity is only one of the factors that could influence compounds biological activity as well as polar, electronic and steric effects. For this family of compounds, lipophilicity does not seem to be a determinant factor for the anti-trypanosomal activity.

\subsection{Insight into the mechanism of action}

\subsubsection{Interference with the intracellular thiol-redox of bloodstream $T$.} brucei

Ferrocenes are known to undergo one electron oxidation, which in biological systems may lead to the formation of radicals through Fenton-like reactions, and, concomitantly, to the oxidation of macromolecules, being thiol groups of proteins and low molecular metabolites (i.e. glutathione) important nucleophilic targets [33,75]. A potential interference of the compounds with the intracellular thiol-redox balance of $T$. brucei was investigated using parasites that express a GFPbased redox biosensor. The biosensor (hGrx-roGFP2) consists of a redox sensitive green fluorescence protein (roGFP2) fused to human glutaredoxin (hGrx) that is able to translate changes in the glutathione/glutathione disulfide (GSH/GSSG) ratio of the medium into changes in its fluorescence intensity (e.g. its oxidation leads to a decrease in its fluorescence intensity at $510 \mathrm{~nm}$ upon excitation at $488 \mathrm{~nm}$ ) [43,54]. The redox biosensor has been shown very sensitive in detecting small increases (nM to low $\mu \mathrm{M}$ ) in the concentration of oxidized glutathione originating from oxidative stress, impaired biosynthesis or reduction of glutathione $[43,76]$.

The parasites were incubated for short times ( 1 or $3 \mathrm{~h}$ ) with compounds added at their $\mathrm{IC}_{50}$, and GFP fluorescence and cell viability estimated (data not shown). Under these conditions most compounds exerted a cytotoxic effect $\leq 27 \%$ but none of them produced a marked and sustained oxidation of the biosensor ( $>20 \%$ at both time points). As expected the redox cycler compound menadione, added at 125 or $250 \mu \mathrm{M}$, produced a significant decrease in fluorescence intensity ( $>80 \%$ ) that was associated with loss of parasite viability ( $>40 \%$ ) [77]. In summary, this suggests that the anti-parasitic effect of the heterobimetallic ferrocenyl derivatives and/or the corresponding ligands (dppf, HHino and HTrop) cannot be ascribed to a major interference of the compounds with the thiol-redox homeostasis of the pathogen.

\subsubsection{DNA interaction}

Ethidium bromide (EB) fluorescent DNA probe was employed to follow the interaction of the new complexes with DNA. EB is a planar molecule with weak intrinsic fluorescence emission at the selected excitation wavelength of $510 \mathrm{~nm}$. In pH 7.4 Tris buffer/5\% DMSO solution it shows an emission maximum at $601 \mathrm{~nm}$. Intercalation of $\mathrm{EB}$ into double stranded DNA induces an increase of the fluorescence quantum yield [78-80]. Additionally, in our experimental conditions the emission maximum of the \{DNA-EB \} adduct is located at $594 \mathrm{~nm}$. At the selected excitation wavelength $\left(\lambda_{\text {exc }}=510 \mathrm{~nm}\right)$ DNA, HHino and HTrop ligands and the M-dppf-Hino and M-dppf-Trop complexes are 

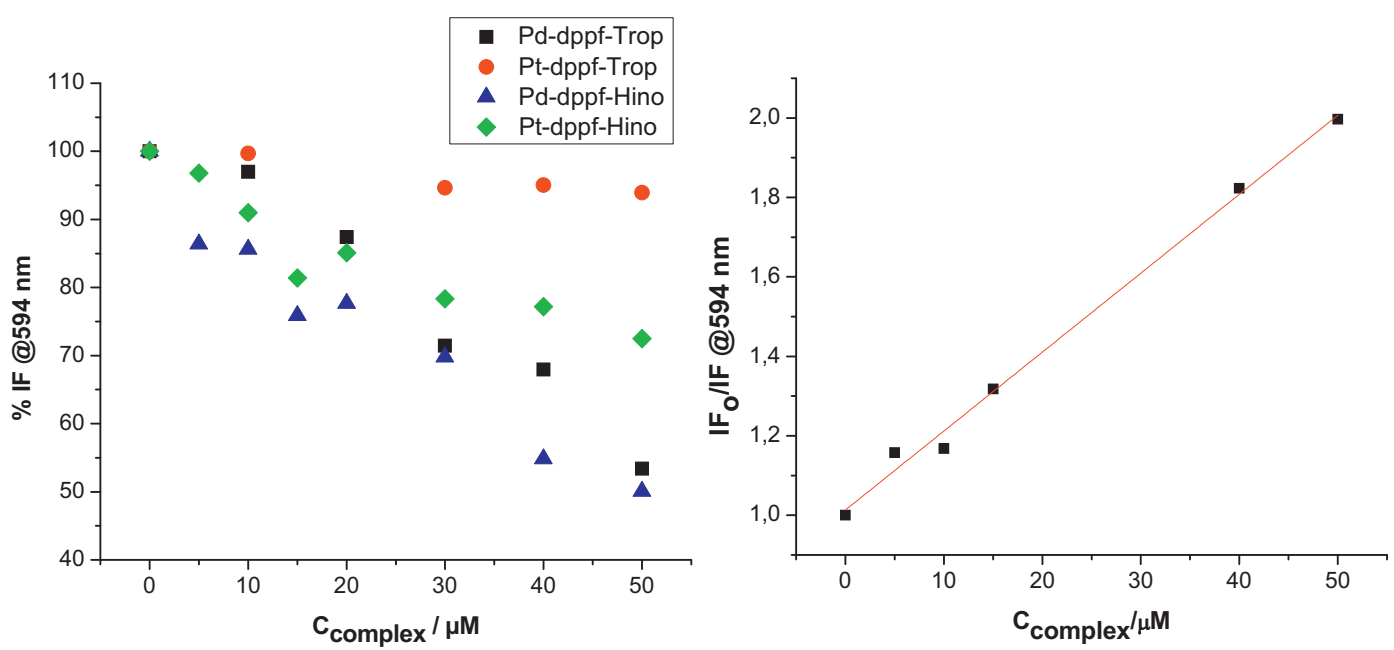

Fig. 3. Left: Relative fluorescence intensity (\%) at $\lambda_{\mathrm{em}}=594 \mathrm{~nm}$ with increasing compound concentration obtained for the four complexes $\left(\mathrm{C}_{\mathrm{DNA}}=20 \mu \mathrm{M}\right.$, $\mathrm{C}_{\mathrm{EB}}=10 \mu \mathrm{M}$, samples prepared in $5 \% \mathrm{DMSO} /$ Tris $\mathrm{HCl}$ medium, 30 min incubation at $37^{\circ} \mathrm{C}$ ). Squares: Pd-dppf-Trop; circles: Pt-dppf-Trop; triangles: Pd-dppf-Hino; diamonds: Pt-dppf-Hino. Right: Stern Volmer plot for [Pd(hino)(dppf)]( $\left.\mathrm{PF}_{6}\right)$.

non-fluorescent in $\mathrm{pH}=7.410 \mathrm{mM}$ Tris/5\% DMSO, and no fluorescence emission results from the direct interaction of the complexes or the ligands with DNA.

Results obtained for the titration of the \{DNA-EB $\}$ adduct with the new compounds are depicted in Fig. 3.

Both, HTrop and HHino ligands do not affect the emission of the \{DNA-EB\} adduct demonstrating no interaction of the free ligands with DNA. A quenching in the emission of $\{$ DNA-EB $\}$ is observed upon increasing concentration of the M-dppf-L complexes, the extent of the quenching being of similar order for the four complexes. These results are consistent with an EB displacement from the \{DNA-EB\} adduct brought upon by the binding of complexes to DNA in an intercalativelike manner or another type of interaction with DNA that induces conformational changes and a concomitant disruption of EB binding sites in the DNA.

The mechanisms involved in the fluorescence quenching process for the complexes can be accessed by a Stern-Volmer analysis according to

$\frac{I_{F 0}}{I_{F}}=1+K_{S V}[Q]$

where $I_{F 0}$ and $I_{\mathrm{F}}$ is the emission fluorescence intensity of the \{DNA-EB\} adduct in the absence and in the presence of the complex, $K_{\mathrm{SV}}$ the SternVolmer constant, and [Q] the concentration of the quencher (in this case, the complexes) [81]. Eq. (1) predicts a linear plot for $I_{\mathrm{F} 0} / I_{\mathrm{F}}$ for a homogeneously emitting system. Stern-Volmer analysis showed a linear $I_{\mathrm{FO}} / I_{\mathrm{F}}$ plot (Fig. 3) and the $K_{\mathrm{SV}}$ constant can be calculated for each system (Table 7). Although $K_{\mathrm{SV}}$ is really related with the quenching produced by the compounds it is an useful parameter indirectly indicative of the affinity of the compounds to DNA.

Results depicted in Table 7, show that all complexes tested interact with DNA in a fashion that is independent of the nature of the metal center (Pd or Pt) and of the tropolone derivative acting as co-ligand. The Pd complexes showed higher DNA affinities than the Pt analogues.

Table 7

Stern-Volmer constants of the M-dppf-Hino and M-dppf-Trop complexes for the competitive binding to \{DNA-EB\} adduct in 5\% DMSO/Tris $\mathrm{HCl}$ medium.

\begin{tabular}{lll}
\hline Complex & $K_{\mathrm{Sv}}\left(\mathrm{M}^{-1}\right)$ & $\log \left(K_{\mathrm{SV}}\right)$ \\
\hline Pd-dppf-Trop & 12,091 & 4.1 \\
Pt-dppf-Trop & 1345 & 3.1 \\
Pd-dppf-Hino & 19,876 & 4.3 \\
Pt-dppf-Hino & 7421 & 3.9 \\
\hline
\end{tabular}

Obtained Ksv values for the four complexes are of similar order to those previously reported by us for other complexes showing antitrypanosomal activity [28,82]. As expected, obtained Ksv values were lower than those previously reported for other complexes with typical planar DNA intercalating ligands [83].

Thus, the results suggest that DNA could be a molecular target of these complexes. Although the number of complexes is low to allow establishing correlations, the slightly higher biological activities of the developed Pd complexes with respect to those observed for the Pt analogues seem to correlate well with the higher affinities of the Pd complexes for DNA. This correlation is in agreement with previously reported results for some series of Pd and Pt analogues showing antitumoral or antitrypanosomal activities [84-86]. In particular, some Pd complexes previously developed by our group showed higher activity on Trypanosoma cruzi together with higher affinity for DNA than the analogous Pt compounds [87].

\section{Conclusions}

Four new ferrocenyl derivatives, $[\mathrm{M}(\mathrm{Trop})(\mathrm{dppf})]\left(\mathrm{PF}_{6}\right)$ and $[\mathrm{M}$ (Hino)(dppf) $\left(\mathrm{PF}_{6}\right)$, with $\mathrm{M}=\mathrm{Pd}(\mathrm{II})$ or $\mathrm{Pt}(\mathrm{II})$, dppf $=1,1^{\prime}$-bis(dipheny1phosphino) ferrocene and HTrop and HHino the bioactive ligands tropolone and hinokitiol, were synthesized and characterized in the solid state and in solution.

The strategy of including the ferrocene moiety as the M-dppf coligand led to new heterobimetallic Pd-Fe and Pt-Fe compounds bearing interesting activity on trypanosomatid parasites. These compounds showed an improvement in activity against Trypanosoma brucei and selectivity towards the parasite with respect to the HTrop, HHino and dppf ligands. The Pd compounds were more active than the Pt analogues but the Pt compounds were less toxic than the Pd ones ( $S I \cong 20$ ). In addition, these compounds were more active than the free ligands against $L$. infantum but low selective towards the parasite. The new hinokitiol and tropolone compounds were also active on Mycobacterium tuberculosis sensitive strain $\mathrm{H} 37 \mathrm{Rv}$ but showed lower activity on resistant clinical isolates and low selectivity towards $M$. tuberculosis.

The antiparasitic effect could not be ascribed to a potential interference of the compounds with the thiol-redox homeostasis of the pathogen but DNA could be a potential target.

The global results point at $\left[\mathrm{Pt}^{\mathrm{II}}(\mathrm{Trop})(\mathrm{dppf})\right]\left(\mathrm{PF}_{6}\right)$ and $\left[\mathrm{Pt}^{\mathrm{II}}\right.$ (Hino) (dppf)] $\left(\mathrm{PF}_{6}\right)$ as the most promising compounds for further anti-T. brucei drug developments. 


\section{Acknowledgements}

F.R. and E.R.A. acknowledge the support of the Agencia Nacional de Investigación e Innovación (ANII, Uruguay) through the grants POS_NAC_2016_1_129899 and POS_NAC_2015_1_110215, respectively. This work was supported by PEDECIBA Uruguay. M.A.C. acknowledges the support of ANII (grant PR_FMV_2009_1_2617) and FOCEM (MERCOSUR Structural Convergence Fund, COF 03/11). The authors thank Prof. L. Suescun for his assistance with $\mathrm{X}$ ray data collection and crystal structure analysis.

\section{Appendix A. Supplementary data}

Supplementary data to this article can be found online at https:// doi.org/10.1016/j.jinorgbio.2018.07.013.

\section{References}

[1] http://www.who.int/topics/tropical diseases/en/, Accessed date: 18 April 2018.

[2] http://www.who.int/neglected_diseases/diseases/en/, Accessed date: 18 April 2018.

[3] K. Stuart, R. Brun, S. Croft, A. Fairlamb, R.E. Gürtler, J. McKerrow, S. Reed, R. Tarl, J. Clin. Invest. 118 (2008) 1301-1310.

[4] N.M. El-Sayed, et al., Science 309 (2005) 404-409.

[5] http://www.who.int/trypanosomiasis_african/en/, Accessed date: 18 April 2018.

[6] L. Scotti, F.J.B. Mendonça, M.S. Da Silva, M.T. Scotti, Curr. Protein Pept. Sci. 17 (2016) 243-259.

[7] M. Berninger, I. Schmidt, A. Ponte-Sucre, U. Holzgrabe, Med. Chem. Commun. 8 (2017) 1872-1890.

[8] V. Delespaux, H.P. de Koning, Drug Resist. Updat. 10 (2007) 30-50.

[9] http://www.who.int/leishmaniasis/en/, Accessed date: 20 April 2018.

[10] S. Sundar, J. Chakravarty, Expert. Opin. Pharmacother. 14 (2013) 53-63.

[11] A.S. Nagle, S. Khare, A. Babu Kumar, F. Supek, A. Buchynskyy, C.J.N. Mathison, N. Kumar Chennamaneni, N. Pendem, F.S. Buckner, M.H. Gelb, V. Molteni, Chem. Rev. 114 (2014) 11305-11347.

[12] World Health Organization, Global Tuberculosis 2016Report, Cdc 2016, 214 (2016) (doi: ISBN 978924156539 4).

[13] World Health Organization, Global Tuberculosis Report, Geneva, (2017) (Doi: WHO/HTM/TB/2017.23).

[14] http://www.who.int/topics/tuberculosis/en/, Accessed date: 18 April 2018.

[15] K.J. Seung, S. Keshavjee, M.L. Rich, Cold Spring Harb. Perspect. Med. 5 (2015) a017863.

[16] A. Zwerling, M.A. Behr, A. Verma, T.F. Brewer, D. Menzies, M. Pai, PLoS Med. 8 (2011), https://doi.org/10.1371/journal.pmed.1001012.

[17] G. Sgaragli, M. Frosini, S. Saponara, F. Corelli, Curr. Med. Chem. 23 (2016) $2245-2274$.

[18] M.J. Ahsan, M.Y. Ansari, S. Yasmin, S.S. Jadav, P. Kumar, S.K. Garg, A. Aseri, H. Khalilullah, Infect. Disord. Drug Targets 15 (2015) 32-41.

[19] R.A. Sánchez-Delgado, A. Anzellotti, L. Suárez, Metal complexes as chemotherapeutic agents against tropical diseases: malaria, trypanosomiasis, and leishmaniasis, in: H. Sigel, A. Sigel (Eds.), Metal ions in Biological Systems, 41 Marcel Dekker, New York, 2004, pp. 379-419.

[20] M. Navarro, G. Gabbiani, L. Messori, D. Gambino, Drug Discov. Today 15 (2010) 1070-1078.

[21] D. Gambino, L. Otero, Inorg. Chim. Acta (2012) 103-114.

[22] D. Gambino, L. Otero, Inorg. Chim. Acta 472 (2018) 58-75.

[23] B. Demoro, C. Sarniguet, R. Sánchez-Delgado, M. Rossi, D. Liebowitz, F. Caruso, C. Olea-Azar, V. Moreno, A. Medeiros, M.A. Comini, L. Otero, D. Gambino, Dalton Trans. 41 (2012) 1534-1543.

[24] B. Demoro, R.F.M. de Almeida, F. Marques, C.P. Matos, L. Otero, J. Costa Pessoa, I. Santos, A. Rodríguez, V. Moreno, J. Lorenzo, D. Gambino, A.I. Tomaz, Dalton Trans. 42 (2013) 7131-7146.

[25] B. Demoro, M. Rossi, F. Caruso, D. Liebowitz, C. Olea-Azar, U. Kemmerling, J.D. Maya, H. Guiset, V. Moreno, C. Pizzo, G. Mahler, L. Otero, D. Gambino, Biol. Trace Elem. Res. 153 (2013) 371-381.

[26] I. Machado, S. Fernández, L. Becco, B. Garat, J.S. Gancheff, A. Rey, D. Gambino, J. Coord. Chem. 67 (2014) 1835-1850.

[27] E. Rodríguez Arce, C. Sarniguet, T.S. Moraes, M. Vieites, A.I. Tomza, A. Medeiros, M.A. Comini, J. Varela, H. Cerecetto, M. González, F. Marques, M.H. García, L. Otero, D. Gambino, J. Coord. Chem. 68 (2015) 2923-2937.

[28] M. Fernández, E. Rodríguez Arce, C. Sarniguet, T.S. Morais, A.I. Tomaz, C. Olea Azar, R. Figueroa, J. Diego Maya, A. Medeiros, M. Comini, M.H. Garcia, L. Otero, D. Gambino, J. Inorg. Biochem. 153 (2015) 306-314.

[29] E. Rodríguez Arce, M.F. Mosquillo, L. Pérez-Díaz, G.A. Echeverría, O.E. Piro, A. Merlino, E.L. Coitiño, C. Maríngolo Ribeiro, C.Q.F. Leite, F.R. Pavan, L. Otero, D. Gambino, Dalton Trans. 44 (2015) 14453-14464.

[30] E. Rodríguez Arce, I. Machado, B. Rodríguez, M. Lapier, M.C. Zúñiga, J.D. Maya, C. Olea Azar, L. Otero, D. Gambino, J. Inorg. Biochem. 170 (2017) 125-133.

[31] R.H. Fish, G. Jaouen, Organometallics 22 (2003) 2166-2177.

[32] C. Biot, Curr. Med. Chem.: Anti-Infect. Agents 3 (2004) 135-147.
[33] C. Biot, D. Dive, Top. Organomet. Chem. 32 (2010) 155-193.

[34] M.F. Mosquillo, L. Bilbao, F. Hernández, F. Tissot, D. Gambino, B. Garat, L. PérezDíaz, Chem. Biol. Drug Des. (2018), https://doi.org/10.1111/cbdd.13332.

[35] S.N. Ononye, M.D. VanHeyst, E. Zachary Oblak, W. Zhou, M. Ammar, A.C. Anderson, D.L. Wright, ACS Med. Chem. Lett. 4 (2013) 757-761.

[36] M. Saniewski, M. Horbowicz, S. Kanlayanarat, J. Hortic. Res. 22 (2014) 5-19.

[37] K. Nomiya, A. Yoshizawa, K. Tsukagoshi, N. Chikaraishi Kasuga, S. Hirakawa, J. Watanabe, J. Inorg. Biochem. 98 (2004) 46-60.

[38] T.A.K. Al-Allaf, H. Schmidt, K. Merzweiler, C. Wagner, D. Steinborn, J. Organomet. Chem. 678 (2003) 48-55.

[39] W.J. Geary, Coord. Chem. Rev. 7 (1971) 81-122.

[40] G.M. Sheldrick, Acta Cryst A64 (2008) 112-122.

[41] O.V. Dolomanov, L.J. Bourhis, R.J. Gildea, J.A.K. Howard, H. Puschmann, J. Appl. Crystallogr. 42 (2009) 339-341.

[42] B. Rees, L. Jenner, M. Yusupov, Acta Cryst D61 (2005) 1299-1301.

[43] J. Franco, A. Medeiros, D. Benítez, K. Perelmuter, G. Serra, M.A. Comini, L. Scarone, Eur. J. Med. Chem. 126 (2017) 776-788.

[44] F. Maiwald, D. Benítez, D. Charquero, M.A. Dar, H. Erdmann, L. Preu, O. Koch, C. Hölscher, N. Loaëc, L. Meijer, M.A. Comini, C. Kunick, Eur. J. Med. Chem. 18 (2014) 274-283.

[45] J.C. Palomino, A. Martin, M. Camacho, H. Guerra, J. Swings, F. Portaels, Antimicrob. Agents Chemother. 46 (2002) 2720-2722.

[46] M. Miyata, F.R. Pavan, D.N. Sato, L.B. Marino, M.H. Hirata, R.F. Cardoso, F.A.F. De Melo, C.F. Zanelli, C.Q.F. Leite, Biomed Pharmacother 65 (2011) 456-459.

[47] N.H. Mendes, F.A.F. Melo, A.C.B. Santos, J.R.C. Pandolfi, E.A. Almeida, R.F. Cardoso, H. Berghs, S. David, F.K. Johansen, L.G. Espanha, S.R.A. Leite, C.Q.F. Leite, BMC. Res. Notes 4 (2011) 269.

[48] I.C. Silva, C.R. Polaquini, L.O. Regasini, H. Ferreira, F.R. Pavan, Food Chem. Toxicol. 105 (2017) 300-307.

[49] F.R. Pavan, P.I. Maia, S.R. Leite, V.M. Deflon, A.A. Batista, D.N. Sato, C.Q. Leite, Eur. J. Med. Chem. 45 (2010) 1898-1905.

[50] C. Hansch, A. Leo, The hydrophobic parameter: measurement and calculation, Exploring QSAR. Fundamentals and Applications in Chemistry and Biology, American Chemical Society Ed, Washington, 1995, pp. 97-124.

[51] H. Cerecetto, R. Di Maio, M. González, M. Risso, P. Saenz, G. Seoane, A. Denicola, G. Peluffo, C. Quijano, C. Olea-Azar, J. Med. Chem. 42 (1999) 1941-1950.

[52] J. Benítez, L. Becco, I. Correia, S. Milena Leal, H. Guiset, J. Costa Pessoa, J. Lorenzo, S. Tanco, P. Escobar, V. Moreno, B. Garat, D. Gambino, J. Inorg. Biochem. 105 (2011) 303-311.

[53] M. Fernández, L. Becco, I. Correia, J. Benítez, O.E. Piro, G.A. Echeverria, A. Medeiros, M. Comini, M.L. Lavaggi, M. González, H. Cerecetto, V. Moreno, J. Costa Pessoa, B. Garat, D. Gambino, J. Inorg. Biochem. 127 (2013) 150-160.

[54] M. Gutscher, A.L. Pauleau, L. Marty, T. Brach, G.H. Wabnitz, Y. Samstag, A.J. Meyer, T.P. Dick, Nat. Methods 5 (2008) 553-559.

[55] J.K. Barton, J.M. Goldberg, Ch.V. Kumar, N.J. Turro, J. Am. Chem. Soc. 108 (1986) 2081-2088.

[56] M.C. Barret, M.F. Mahon, K.C. Molloy, J.W. Steed, P. Wright, Inorg. Chem. 40 (2001) 4384-4388.

[57] H. Junge, Spectrochim. Acta A: Mol. Spectrosc. 24 (1968) 1957-1963.

[58] B.S. Parajón-Costa, E.J. Baran, J. Romero, R. Sáez-Puche, G. Arrambide, D. Gambino, J. Coord. Chem. 64 (2011) 57-70.

[59] T. Hayashi, M. Konishi, Y. Kobori, M. Kumada, T. Higuchi, K. Hirotsu, J. Am. Chem. Soc. 106 (1984) 158-163.

[60] A.M. Heyns, Spectrochim. Acta A: Mol. Spectrosc. 33 (1977) 315-322.

[61] A. Camard, Y. Ihara, F. Murata, K. Mereiter, Y. Fukuda, W. Linert, Inorg. Chim. Acta 358 (2005) 409-414.

[62] K. Nomiya, K. Onodera, K. Tsukagoshi, K. Shimada, A. Yoshizawa, T. Itoyanagi, A. Sugie, S. Tsuruta, R. Sato, N. Chikaraishi Kasuga, Inorg. Chim. Acta 362 (2009) 43-55.

[63] D.J. Bertelli, T.G. Andrews, P.O. Crews, J. Am. Chem. Soc. 91 (1969) 5286-5296.

[64] K. Lyczko, M. Lyczko, K. Wozniak, M. Stachowicz, W.P. Oziminski, K. Kubo, Inorg. Chim. Acta 436 (2015) 57-68.

[65] M. Hojo, T. Ueda, M. Ike, K. Okamura, T. Sugiyama, M. Kobayashi, H. Nakai, J. Chem. Eng. Data 55 (2010) 1986-1989.

[66] A. Togni, T. Hayashi, "Ferrocenes: Homogeneous Catalysis, Organic Synthesis, Materials Science" Weinheim - New York Basel - Cambridge. Tokyo, (1995).

[67] L. Maisela, A.M. Crouch, J. Darkwa, I.A. Guzei, Polyhedron 20 (2001) 3189-3200.

[68] C.E. Housecroft, S.M. Owen, P.R. Raithby, B.A.M. Shaykh, Organometallics 9 (1990) 1617-1623.

[69] D. Cauzzi, C. Graiff, C. Massera, G. Predieri, A. Tiripicchio, D. Acquotti, J. Chem. Soc. Dalton Trans. (1999) 3515-3521.

[70] P. Vincendeau, B. Bouteille, An. Acad. Bras. Cienc. 78 (2006) 645-665.

[71] D. Benítez, A. Medeiros, L. Fiestas, E.A. Panozzo-Zenere, F. Maiwald, K.C. Prousis, M. Roussaki, T. Calogeropoulou, A. Detsi, T. Jaeger, J. Šarlauskas, L. Peterlin Mašič, C. Kunick, G.R. Labadie, L. Flohé, M.A. Comini, PLoS Negl. Trop. Dis. 10 (2016) e0004617.

[72] World Health Organization (WHO), Special programme for research and training in tropical diseases (TDR), http://apps.who.int/tdr/documents/bl-2008-businessplan-2008.pdf, Accessed date: 30 November 2014.

[73] I. Orme, Antimicrob. Agents Chemother. 45 (2001) 1943-1946.

[74] E.H. Kerns, L. Di, Drug-like Properties: Concepts, Structure Design and Methods From ADME to Toxicity Optimization, Academic Press, Amsterdam, 2008.

[75] F. Dubar, T.J. Egan, B. Pradines, D. Kuter, K.K. Ncokazi, D. Forge, J.F. Paul, C. Pierrot, H. Kalamou, J. Khalife, E. Buisine, C. Rogier, H. Vezin, I. Forfar, C. Slomianny, X. Trivelli, S. Kapishnikov, L. Leiserowitz, D. Dive, C. Biot, ACS Chem. Biol. 6 (2011) 275-287. 
[76] J. Franco, F. Sardi, L. Szilágyi, K.E. Kövér, K. Fehér, M.A. Comini, Int. J. Parasitol. Drugs Drug Resist. 7 (2017) 303-313.

[77] M. Boiani, L. Piacenza, P. Hernández, L. Boiani, H. Cerecetto, M. González, A. Denicola, Biochem. Pharmacol. 79 (2010) 1736-1745.

[78] J. Le Pecq, P. Yot, C. Paoletti, C. R. Acad. Sci. 259 (1964) 1786-1789.

[79] M.J. Waring, J. Mol. Biol. 13 (1965) 269-282.

[80] C. Tan, J. Liu, L.M. Chen, S. Shi, L.N. Ji, J. Inorg. Biochem. 102 (2008) 1644-1653.

[81] J.R. Lakowicz, Principles of Fluorescence Spectroscopy, 3rd. ed., Springer Science, New York, 2006 (Chapter 8).

[82] M. Cipriani, J. Toloza, L. Bradford, E. Putzu, M. Vieites, E. Curbelo, A.I. Tomaz, B. Garat, J. Guerrero, J.S. Gancheff, J.D. Maya, C. Olea Azar, D. Gambino, L. Otero, Eur. J. Inorg. Chem. 27 (2014) 4677-4689.
[83] B. Wu, L. Gao, Z. Duan, K. Wang, J. Inorg. Biochem. 99 (2005) 1685-1691.

[84] S. Ghosh, O. Mendoza, L. Cubo, F. Rosu, V. Gabelica, A.J.P. White, R. Vilar, Chem. Eur. J. 20 (2014) 4772-4779.

[85] A.I. Matesanz, E. Jimenez-Faraco, M.C. Ruiz, L.M. Balsab, C. Navarro Ranninger, I.E. León, A.G. Quiroga, Inorg. Chem. Front. 5 (2018) 73-83.

[86] D. Santos, B. Parajón-Costa, M. Rossi, F. Caruso, D. Benítez, J. Varela, H. Cerecetto, M. González, N. Gómez, M.E. Caputto, A.G. Moglioni, G.Y. Moltrasio, L.M. Finkielsztein, D. Gambino, J. Inorg. Biochem. 117 (2012) 270-276.

[87] M. Vieites, P. Smircich, M. Pagano, L. Otero, F. Luane Fischerc, H. Terenzi, M.J. Prieto, V. Moreno, B. Garat, D. Gambino, J. Inorg. Biochem. 105 (2011) 1704-1711. 